\title{
ASSESSING UPLAND RICE, BIOCHAR AND SOIL NUTRIENT MODULES IN THE GUINEAN SAVANNA ZONE (NYANKPALA) GHANA
}

\author{
Frimpong-Manso $\mathrm{J}^{{ }^{*}}$ and Abdul Ganiyu $\mathrm{SA}^{2}$ \\ ${ }^{I}$ CSIR-Soil Research Institute, Academy Post Office, Kwadaso-Kumasi, Ghana \\ ${ }^{2}$ Department of Agricultural Engineering, University for Development Studies, Post Office \\ Box TL1350 Tamale, Ghana
}

\begin{abstract}
The Agricultural Production System simulator (APSIM) is a cropping modeling program that is employed to address research on intercropping systems. We tested it in the Guinea Savannah zone to increase nutrient and nutrient use efficiency to alter agricultural practices in rice-based farming system. Our approach was to calibrate and test the models Upland rice (Oryza sativa L.) and cowpea (Vigna unguiculata L.) intercrop, the interactions between crop growth and soil nitrogen $(\mathrm{N})$, surface organic matter, biochar and the assessment of model projections against independent data sets. During calibration, parameters for crops and soil were developed to ensure that the model adequately captures soil nutrient dynamics under three different biochar plus half rate of inorganic fertilizer root mean square error (RMSE). Soil inorganic N dynamics RMSE 0.18 and $0.216 \mathrm{~kg} \mathrm{~N}$ $\mathrm{ha}^{-1}$ for 2018 and 2019 respectively, contrasting soil $\mathrm{N}$ mineralization patterns under the combination of biochar and inorganic fertilizer applications RMSE 3.86 and $3.18 \mathrm{~kg} \mathrm{~N}^{-1}$ for 2018 and 2019 respectively, straw N uptake RMSE 6.71 and $6.67 \mathrm{~kg} \mathrm{~N}$ ha $^{-1}$ for 2018 and 2019 respectively, grain N uptake RMSE 478.62 and $605.33 \mathrm{~kg} \mathrm{ha}^{-1}$ for 2018 and 2019 respectively. The calibrated model was evaluated against independent data on grain yield RMSE 315.18 and $460.04 \mathrm{~kg} \mathrm{ha}^{-1}$ for 2018 and 2019 respectively, straw production RMSE 183.64 and $100.08 \mathrm{~kg} \mathrm{ha}^{-1}$ for 2018 and 2019 respectively and with a highly acceptable yield, particularly with respect to return-N relations. APSIM has proven to be a reliable model for research and decision-making to improve production systems in upland ricecowpea intercrop in Nyankpala.
\end{abstract}

Keywords: Agricultural Production System simulator (APSIM), nutrient use efficiency, biochar, intercropping

\section{Introduction}

Rice (Oryza sativa) is one of the most significant food crops in the world. Demand for rice has been rising in Africa. The past16-year period (1985 to 2001), rice imports to Africa increased from the initial 3 million tons to over 7 million tons per annum thus, becoming an important food crop in the context of food security. In Ghana and other West African countries, cereal and grain crops, including rice, are essential component of staple food. There are concerns about steady decline in grain yields in Sub-Saharan Africa due to soil degradation which severely threatens crop production and consequently, food security (De Jager et al., 2013). Degradation of cropland is mainly due to continuous cultivation without appropriate soil management practices (Bationo et al., 2007). Cereal production in semi-arid areas of Ghana, as in other savannah regions of West Africa, is heavily affected by inadequate or poorly dispersed rainfall, and low levels of nutrients such as Nitrogen $(\mathrm{N})$, 
Phosphorus (P) in soils (Asekabta, 2018). Moreover, P deficiency reduces the response of crops to mineral N (MacCarthy et al., 2009 and Haji, 2016). Having sustainable yields would require substantial investments in mineral fertilizers (Zhang et al., 2011), because nutrient recycling does not make up for the removal of these nutrients from the soil by harvesting. While soils are depleting in nutrients, the use of mineral fertilizers to enhance crop production is low in this area (De Jager et al., 2019).

Recently, biochar has gained substantial consideration as soil amendment, owing to its agronomic support and carbon sequestration potential. Biochar has beneficial properties such as, high surface area (Laird et al., 2010), small particle sizes (Dokoohak et al., 2017), low bulk density (Downie et al., 2012), high organic carbon content (Herath et al., 2014) etc., which together contributes to its ability to reduce soil bulk density, raise porosity and aid coarse textured soils by increasing their water holding capacity (Basso et al., 2013). Short-term variations in physical and hydrological properties of soils have been achieved through biochar incorporation in several laboratory and on--station trial studies (Streubel et al., 2011).

The Agricultural Production Systems Simulator (APSIM) model features a user-friendly interface that provides advanced flexibility in the implementation of simple and complex simulations without the need to write additional codes, i.e., intercropping systems (McCown et al., 2016; Nelson, 2020) inclusive of annual or perennial species. The transition from seasonal and sequential analysis is straightforward and the model also provides a rich graphical interface (Archontoulis et al., 2014; Martinez-Feria et al., 2018). Cropping systems models such as APSIM (Holzworth et al., 2014; Keating et al., 2003) include intercropping of grain, legumes and applications of organic (biochar) and mineral fertilizers, describing the dynamics of crop growth and soil nutrients. The model has been used successfully within the pursuit for strategies for more efficient production, improved risk management, crop adaptation, and sustainable production (Keating et al., 2003; Van Ittersum et al., 2016). The main objective is to investigate modeling dynamics and accumulation of inorganic NPK in the plant and the yield response to three different sources of biochar and fertilizer under rainfed conditions.

\section{Materials and Methods}

\section{Field Experiment and Measurements}

\section{Study area}

A field experiment over two consecutive cropping seasons (2018-2019). The research site was located at the Farming for the Future, University for Development Studies (UDS), Nyankpala near Tamale in the Northern Region of Ghana (latitude $09.246070 \mathrm{~N}$ and longitude $000.589920 \mathrm{~W}$ ). The area has a unimodal rainfall pattern with an annual rainfall of 800-1100 mm (Kombiok et al., 2005). The dry season starts from November to March with day temperatures ranging from $33{ }^{\circ} \mathrm{C}$ to $39{ }^{\circ} \mathrm{C}$, with night temperatures range from $20{ }^{\circ} \mathrm{C}$ to $26^{\circ} \mathrm{C}$ (Kombiok et al., 2005). The mean annual daytime relative humidity is $54 \%$ with altitude of the area is $252 \mathrm{~m}$ above sea level. The site is underlain by Upper Voltaian sediments. The area is covered with red and orange-brown drifts partly eroded in places and exposing a layer of shallow ironstone and sandstone brash (Adu, 1995). 
The layer is often separated from the underlying sandstone by a thin stone-lime (Adu, 1995). The soil profile has been classified as Nyankpala series (Ferric luvisols and Plinthic acrisols) (ISSS/ISRIC/ FAO, 1998; FAO-UNESCO, (1988). They are shallow to very shallow soils overlying in situ developed iron pan within $55.9 \mathrm{~cm}$. It is also moderately shallow to moderately deep concretionary and or gravelly, heavy to medium textured soils overlying mostly highly weathered granites shales (Asiamah, 2008). Characteristically the soils are acidic, with low nitrogen and phosphorus content. They are susceptible to moderate erosion and should not, therefore be left bare. They are inherently infertile and will need to be fertilized to obtain optimum yield (Adu, 1995).

\section{Biochar preparation}

Three different sources of feedstocks were produced from slow and high pyrolysis of groundnut shells, corn cobs, poultry manure at $400{ }^{\circ} \mathrm{C}-700{ }^{\circ} \mathrm{C}$ with a dwelling time of 24 hours in oxygenlimited conditions in a reactor, followed by water and air cooling of charred feedstock to room temperature and grind the biochar. Chemical characteristics of the biochar applied are shown in Table 1. Organic carbon was determined by the wet combustion method according to Walkley and Black (1934). Total nitrogen was determined by the kjeldahl method Phosphorus and potassium were determined in plant ash using the analyzed with flame photometry (Pratt 1965). Available phosphorus was determined according Bray and Kutz (1945).

\section{Experimental design and data collection}

The field experiment was established in June 2017 and initiated with a single application of the three different sources of biochar to the experiment. The experiment was laid out in randomized complete blocks (RCBD) with 4 replications. The crops were Nerica 14 (African upland rice) days of maturity was 85 days for the rice (Oryza sativa L.) and erect cowpea (padituya) type (Vigna unguiculata L.). Nerica 14 seeds were soak in water to separate unfilled grains from filled grain and then dried at room temperature for 24 hours. The seeds were drilled in rice husk biochar at $3 \mathrm{~cm}$ below the biochar surface in rows $30 \mathrm{~cm}$ apart and this was to maintain moisture for good germination. Weeds were controlled by hand twice before transplanting. After three weeks, transplanting was done on the $28^{\text {th }}$ for rice and $29^{\text {th }}$ for cowpeas in July, 2018 and $21^{\text {st }}$ and $22^{\text {nd }}$ July, 2019 at a rate of two seedlings per hole. Planting distance for rice was $20 \mathrm{~cm}$ x $20 \mathrm{~cm}$ and cowpea $60 \mathrm{~cm}$ x $20 \mathrm{~cm}$. The combination of the rice and cowpea was in a 3:1 ratio. The treatment includes a control (no input), fertilizer and cowpea intercrop either applied alone or in combination with the three different sources of biochar. Biochar levels were $5 \mathrm{t} \mathrm{ha}^{-1}$ each and was incorporated into the soil at the same time. Inorganic fertilizer was applied at a rate of 90,60,60 and 45, 30, $30 \mathrm{~kg} \mathrm{ha}^{-1} \mathrm{NPK}$, as straight fertilizer and then top-dress with nitrogen levels in the form of urea $30 \mathrm{~kg} \mathrm{ha}^{-1} \mathrm{~N}$ eight (8) weeks after transplanting. Weeds were controlled by hand four counts during the season.

The data used in the current study cover the main crop and soil processes Soil sampling at $0-30 \mathrm{~cm}$ depth for both chemical, physical analysis (bulk density and porosity was determined weekly till harvesting (Table 2). Ten plants were randomly selected on each plot and plant height at maturity, number of panicles, number of tillers and number of grains per panicle determined.

Data was collected every week from 30 days after transplanting to heading. At maturity $1 \mathrm{~m}^{2}$ in each plot were harvested for yield. Data collected at maturity included measurements plant height, number 
of panicles, and number of plants within $1 \mathrm{~m}$ area. Five panicles were randomly selected for number of spikelet's, panicle length, number of grains per spikelet on a panicle, weight of unfilled and filled grains, total grain weight and 1000 grain weight, straw weight. Data were determined by APSIM modules version 7 .

\section{Biochar Types}

Table 1: Basic biochar properties used for simulations

\begin{tabular}{lllllllll}
\hline Feedstock & Pyrolysis & pH 1:5 & $\begin{array}{l}\text { C.E.C } \\
\text { me 100g-1 }\end{array}$ & $\begin{array}{l}\mathrm{N} \\
\%\end{array}$ & $\begin{array}{l}\text { P } \\
\%\end{array}$ & $\begin{array}{l}\mathrm{K} \\
\%\end{array}$ & $\begin{array}{l}\text { C:N } \\
\text { ratio } \\
(-)\end{array}$ & $\begin{array}{l}\text { Fraction C } \\
(0-1)\end{array}$ \\
\hline $\begin{array}{l}\text { Biochar Corn cobs } \\
\begin{array}{l}\text { Biochar Poultry } \\
\text { manure }\end{array}\end{array}$ & High & 6.67 & 118.26 & 0.95 & 0.21 & 0.45 & 11.0 & 0.129 \\
$\begin{array}{l}\text { Biochar Groundnut } \\
\text { shells }\end{array}$ & Low & 9.29 & 125.63 & 2.19 & 0.5 & 0.47 & 10.5 & 0.324 \\
\hline
\end{tabular}

\section{Climatic weather during the cropping Season 2018-2019}

The rainy season's peak happened in July for the current time slice, while a change in the rainfall peak toward August was predicted for the future time slice. The months of August, October, and November are expected to see significant increases in monthly rainfall in the future. The month with the most rainfall was August (Figure 1). Since sandy loam soils dry out rapidly due to their low permanent wilting point, accessible water, and water storage capacity, good crop yields are strongly dependent on a well-distributed rainfall pattern. In the wet season of 2018-2019, Figure 1 depicts the study area seasonal water balance. In 2018-2019, the total rainfall was $133.29 \mathrm{~mm}$, while the total evapotranspiration was $37.10 \mathrm{~mm}$. The upland rice was planted in June of 2018 and 2019, and harvested in November of the same month. From July through October, $61.81 \mathrm{~mm}$ of rain fell, while $3.07 \mathrm{~mm}$ of evapotranspiration fell (Figure 1). During the rice growth phase, from July to August, the table shows a favorable moisture balance. From July to August, rainfall increased and evapotranspiration decreased dramatically. However, because the September rainfall was lower, there was a slight water deficit after August. During the upland rice growing season, there was drought. As a result, biochar amended had a higher yield than non-biochar amended. The significant drop in average temperatures during the upland rice's growth phase (Figure 1) also contributed to a decrease in evapotranspiration, which favoured the rice plant. 


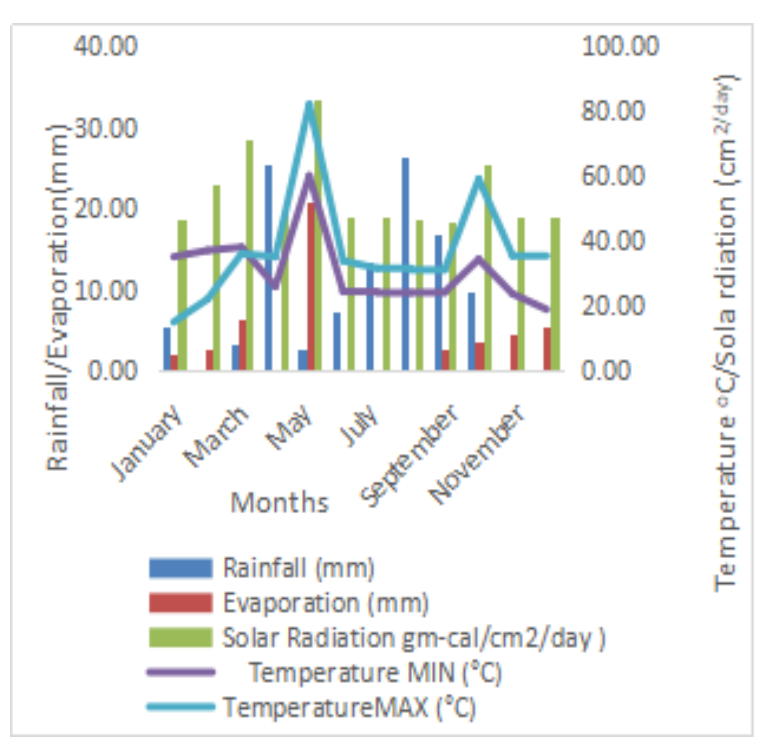

1a. climatic weather for 2018

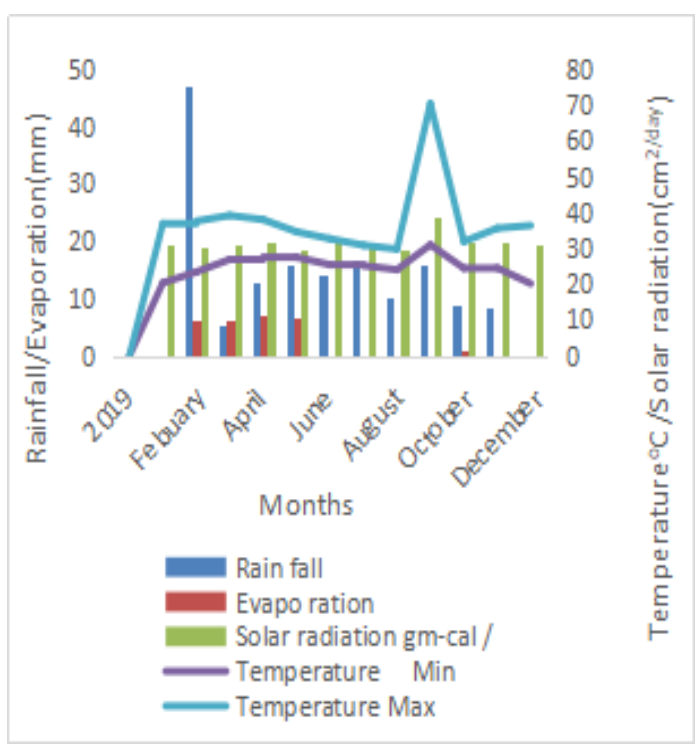

1b. climatic weather for 2019

Figure 1. Summary of climatic weather observed at the study site from 2018 - 2019 Cropping Season

\section{Statistical Indices for Model Performance}

The goodness of fit was evaluated by calculating the root mean square error (RMSE) and absolute errors (MAE). These indices are used to measure absolute and relative errors, respectively, between observed and simulated values. The higher the value, the better. The corresponding equation is available in Archontoulis and Miguez (2014).

\section{Results}

Table 2. Soil profile parameters used in this study

\begin{tabular}{llllll}
\hline Soil Layer & 1 & 2 & 3 & 4 & 5 \\
\hline Layer thickness (cm) & $0-15$ & $15-30$ & $30-60$ & $60-90$ & $90-120$
\end{tabular}

Soil water parameters

$\mathrm{BD}$

(g/cm3)

$\operatorname{SAT}\left(\mathrm{mm}^{-1}\right)$

$\operatorname{DUL}\left(\mathrm{mm}^{-1}\right)$

$\operatorname{LL} 15\left(\mathrm{~mm}^{-1}\right)$

Soil-C parameters

$\mathrm{OC}(\%)$

$\mathrm{pH}\left(\mathrm{H}_{2} \mathrm{O}\right)$

finerta
1.58

0.354

0.202

0.050
1.62

0.358

0.204

0.106
1.57

0.368

0.201

0.153
1.59

0.342

0.198

0.128
1.57

0.339

0.132

0.198
0.47

4.66

0.36
0.41

4.66

0.36
0.33

4.66

0.70
0.38

4.56

0.90
0.33

4.56

0.90 


\begin{tabular}{|c|c|c|c|c|c|}
\hline fbiomb & 0.016 & 0.02 & 0.02 & 0.01 & 0.01 \\
\hline Soil P parameter & & & & & \\
\hline $\begin{array}{l}\text { Labile P } \\
\left(\mathrm{Mg} \mathrm{kg}^{-1}\right)\end{array}$ & 11.6 & 5.8 & 5.0 & 2.0 & 1.0 \\
\hline $\mathrm{P}$ sorption $\left(\mathrm{mg} \mathrm{kg}^{-1}\right)$ & 60 & 80 & 150 & 180 & 200 \\
\hline
\end{tabular}

Soil parameterization of ferric Luvisols at farming for the future, UDS experimental farm to specify APSIM simulations. LL, lower limit; DUL, drained upper limit; SAT, saturated volumetric water content; BD, bulk density; OC, organic carbon; Fbiom, non-inert fraction of microbial C; and Finert, inert fraction of organic $\mathrm{C}$.

Table 3. Nutrient uptake ( $\mathrm{kg} \mathrm{ha-1)}$ in 2018 and 2019 cropping season of rice straw grown at different treatment levels

\begin{tabular}{|c|c|c|c|c|c|c|c|c|}
\hline \multirow{3}{*}{ Treatment } & \multicolumn{4}{|c|}{ Rice Straw - 2018} & \multicolumn{4}{|c|}{ Rice Straw - 2019} \\
\hline & $\mathrm{N}$ & $\mathrm{SO}_{4}-\mathrm{S}$ & $\mathrm{K}$ & $\mathrm{P}$ & $\mathrm{N}$ & $\begin{array}{l}\mathrm{SO}_{4-}- \\
\mathrm{S}\end{array}$ & $\mathrm{K}$ & $\mathrm{P}$ \\
\hline & $\%$ & & & & & & & \\
\hline Absolute Control & 0.69 & 0.45 & 1.30 & 0.14 & 0.08 & 0.50 & 1.96 & 0.15 \\
\hline $90 \mathrm{~N} 60 \mathrm{P} 60 \mathrm{~K}$ & 1.36 & 0.41 & 1.78 & 0.19 & 1.33 & 0.45 & 1.75 & 0.18 \\
\hline CharGroundnutshell+45N30P30K+C & 1.25 & 0.55 & 1.80 & 0.20 & 1.19 & 0.57 & 2.24 & 0.17 \\
\hline CharPoultry manure+45N30P30K+C & 1.44 & 0.57 & 1.65 & 0.25 & 1.41 & 0.58 & 2.94 & 0.29 \\
\hline CharCorn cobs $+45 \mathrm{~N} 30 \mathrm{P} 30 \mathrm{~K}+\mathrm{C}$ & 1.27 & 0.55 & 1.85 & 0.20 & 1.09 & 0.51 & 2.00 & 0.22 \\
\hline CharGroundnut shell+45N30P30K & 1.08 & 0.51 & 1.81 & 0.18 & 1.13 & 0.46 & 2.10 & 0.16 \\
\hline CharPoultry Manure+45N30P30K & 1.02 & 0.52 & 1.29 & 0.23 & 1.08 & 0.44 & 2.43 & 0.35 \\
\hline CharCorn cobs+45N30P30K & 1.02 & 0.48 & 1.80 & 0.25 & 0.94 & 0.46 & 2.04 & 0.21 \\
\hline Grand Mean & 1.15 & 0.51 & 1.67 & 0.20 & 0.94 & 0.50 & 2.20 & 0.20 \\
\hline
\end{tabular}

Char-biochar, Nitrogen (N), Phosphorus (P), Potassium (K) and Sulfur, Cowpea (C)

Table 4. Efficiency of utilization ( $\mathrm{kg} \mathrm{ha}^{-1}$ ) of rice grain absorbed nutrients on biochar and inorganic fertilizer in the seasons 2018 and 2019.

\begin{tabular}{|c|c|c|c|c|c|c|}
\hline Treatment & $\begin{array}{l}\text { Nutrient Use } \\
\text { Efficiency }(\% \mathrm{~N}) \\
2018\end{array}$ & $\begin{array}{l}\text { Nutrient Use } \\
\text { Efficiency } \\
(\% \mathrm{~N}) \\
2019\end{array}$ & $\begin{array}{l}\text { Nutrient } \\
\text { Use } \\
\text { Efficiency } \\
(\% \text { P) } \\
2018\end{array}$ & $\begin{array}{l}\text { Nutrient } \\
\text { Use } \\
\text { Efficiency } \\
(\% \mathrm{P}) \\
2019\end{array}$ & $\begin{array}{l}\text { Nutrient } \\
\text { Use } \\
\text { Efficiency } \\
(\% \mathrm{~K}) \\
2018\end{array}$ & $\begin{array}{l}\text { Nutrient } \\
\text { Use } \\
\text { Efficienc } \\
\text { y }(\% \mathrm{~K}) \\
2019\end{array}$ \\
\hline Control & 1.25 & 1.28 & 0.46 & 0.38 & 0.22 & 0.23 \\
\hline 90N60P60K & 16.63 & 20.96 & 16.65 & 21.10 & 16.65 & 23.60 \\
\hline $\begin{array}{l}\text { CharGroundnutshe } \\
11+45 N 30 \mathrm{P} 30 \mathrm{~K}+\mathrm{C}\end{array}$ & 20.39 & 22.32 & -71.46 & 22.44 & 20.42 & 27.92 \\
\hline $\begin{array}{l}\text { CharPoultrymanur } \\
\text { e+45N30P30K+C }\end{array}$ & 27.04 & 25.31 & 39.81 & 25.38 & 27.07 & 26.32 \\
\hline $\begin{array}{l}\text { CharCorn cobs } \\
45 N 30 \mathrm{P} 30 \mathrm{~K}+\mathrm{C}\end{array}$ & 15.11 & 18.63 & -1.57 & 18.69 & 15.14 & 20.98 \\
\hline $\begin{array}{l}\text { CharGroundnut } \\
\text { shell }\end{array}$ & 4.55 & 16.35 & 0.49 & 16.48 & 4.55 & 17.38 \\
\hline
\end{tabular}




\begin{tabular}{lcccccc}
$\begin{array}{l}\text { Char Poultry } \\
\text { Manure }\end{array}$ & 1.81 & 16.93 & -0.81 & 16.98 & 1.81 & 18.84 \\
CharCorn cobs & 6.59 & 14.02 & -2.69 & 14.07 & 6.59 & 12.76 \\
\hline Grand Mean & 9.67 & 17.29 & -0.83 & 17.21 & 9.61 & 17.16 \\
\hline
\end{tabular}

Char-biochar, Nitrogen (N), Phosphorus (P) and Potassium (K)

Table 5a. Quantitative simple linear correlation coefficients for quality parameters for 2018

\begin{tabular}{lllllll}
\hline & Total grain & $\begin{array}{l}\text { Rice } \\
\text { biomass }\end{array}$ & $\begin{array}{l}\text { Rice } \\
\text { straw }\end{array}$ & $\begin{array}{l}\text { Rice } \\
\text { chlorophyll }\end{array}$ & $\begin{array}{l}\text { Rice } \\
\text { LAI }\end{array}$ & $\begin{array}{l}\text { Rice } \\
\text { canopy }\end{array}$ \\
\hline Total grain & 1 & & & & & \\
Rice biomass & 0.09 & 1 & & & & \\
Rice straw & $0.62^{* *}$ & 0.16 & 1 & & & \\
Rice & & & & & & \\
Chlorophyll & $0.71^{* *}$ & 0.19 & $0.75^{* *}$ & 1 & & \\
Rice LAI & $0.65^{* *}$ & 0.33 & $0.59^{* *}$ & $0.65^{* *}$ & 1 & \\
Rice canopy & $0.54^{* *}$ & 0.28 & 0.62 & $0.51^{* *}$ & $0.73^{* *}$ & 1 \\
\hline
\end{tabular}

$*$ and $* *$ refer to significance at 5 and $1 \%$ confidence levels, respectively

Table 5b. Quantitative simple linear correlation coefficients for quality parameters for 2019

\begin{tabular}{lllllll}
\hline & $\begin{array}{l}\text { Total } \\
\text { grain }\end{array}$ & Rice biomass & $\begin{array}{l}\text { Rice } \\
\text { straw }\end{array}$ & Rice chlorophyll & $\begin{array}{l}\text { Rice } \\
\text { LAI }\end{array}$ & $\begin{array}{l}\text { Rice } \\
\text { canopy }\end{array}$ \\
\hline Total grain & 1 & & & & & \\
Rice biomass & -0.010 & 1 & & & & \\
Rice straw & $0.59^{* *}$ & -0.12 & 1 & & & \\
Rice chlorophyll & $0.73^{* *}$ & 0.12 & $0.65^{* *}$ & 1 & & \\
Rice LAI & $0.61^{* *}$ & 0.03 & $0.53^{* *}$ & $0.70^{* *}$ & 1 & \\
Rice canopy & $0.75^{* *}$ & -0.15 & $0.73^{* *}$ & $0.83^{* *}$ & $0.54^{* *}$ & 1 \\
\hline
\end{tabular}

$*$ and $* *$ refer to significance at 5 and $1 \%$ confidence levels, respectively

- Control - Measured - Simulated Control — Simulated Measured 


\section{A. $90 N 60 P 60$}
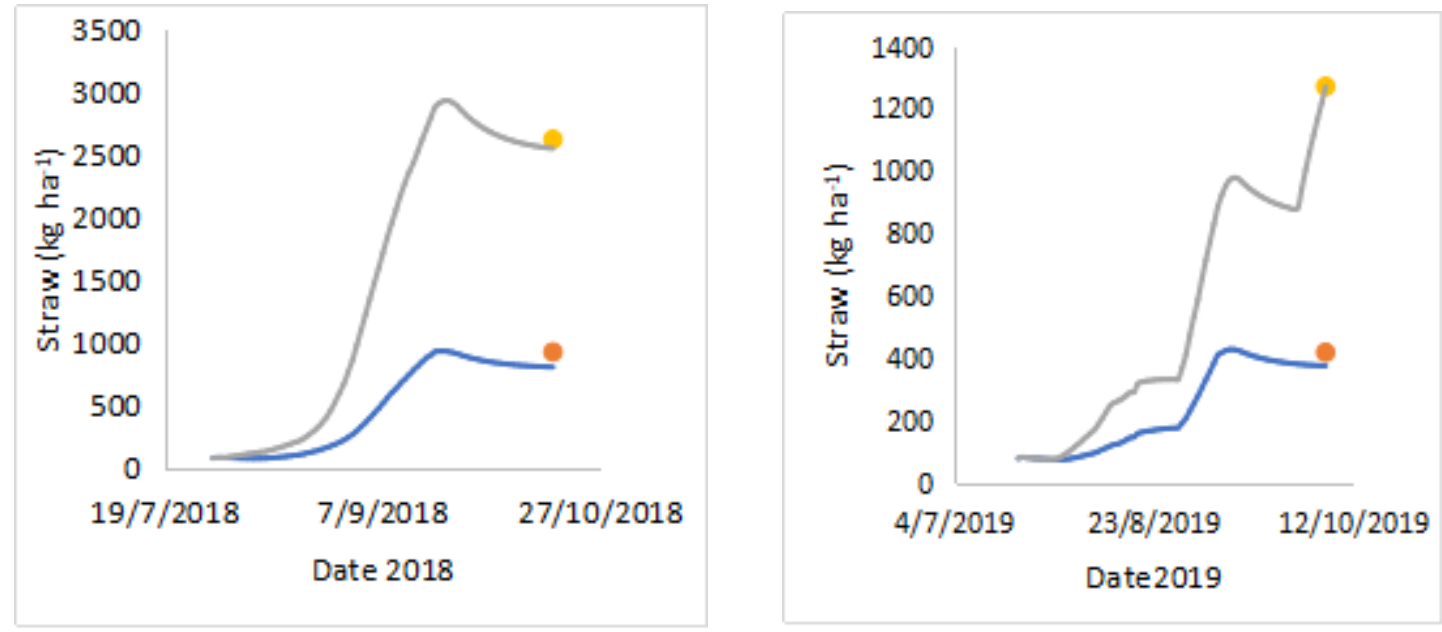

B. Biochar groundnut shells
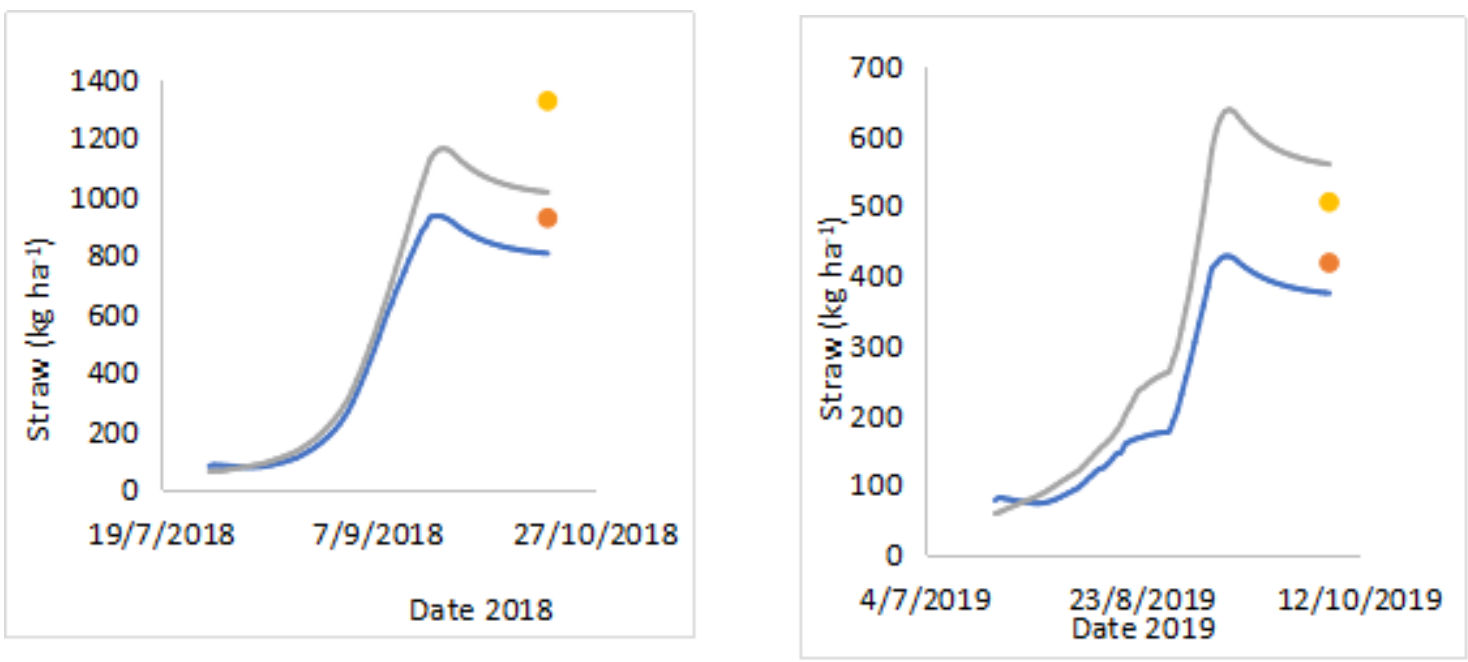

C. Biochar Corn cobs
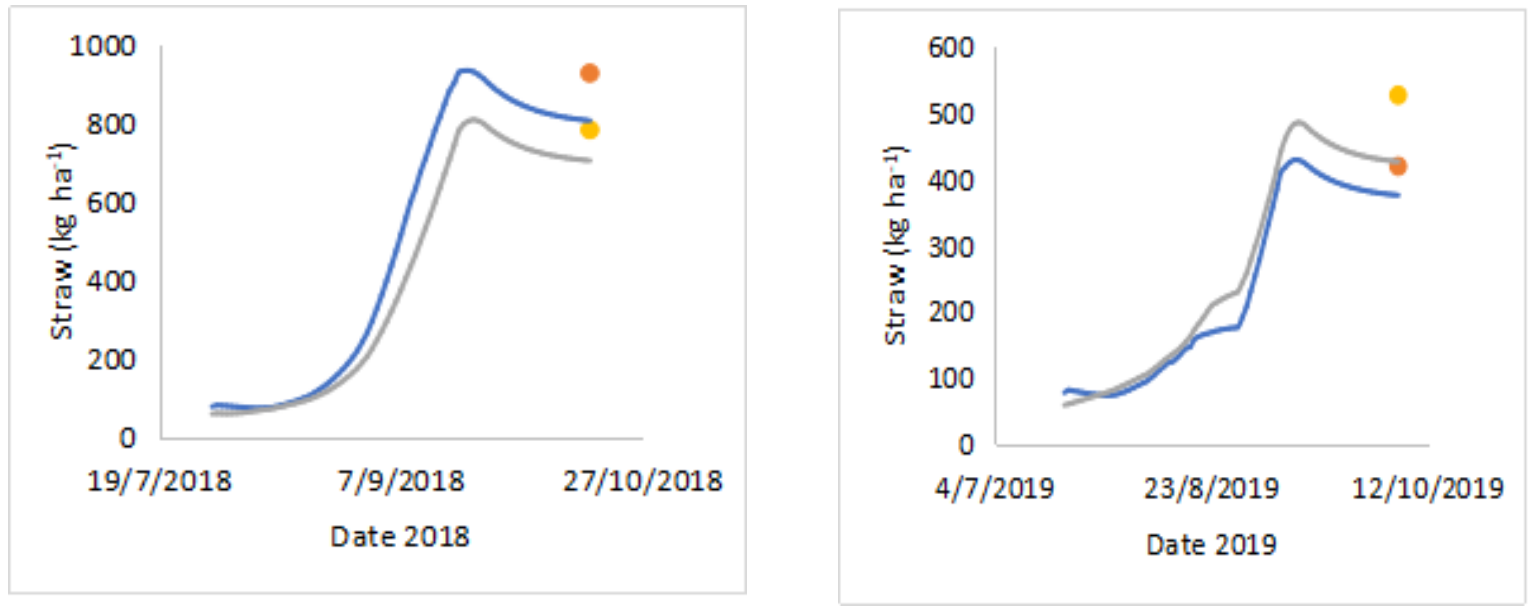
D. Biochar Poultry manure

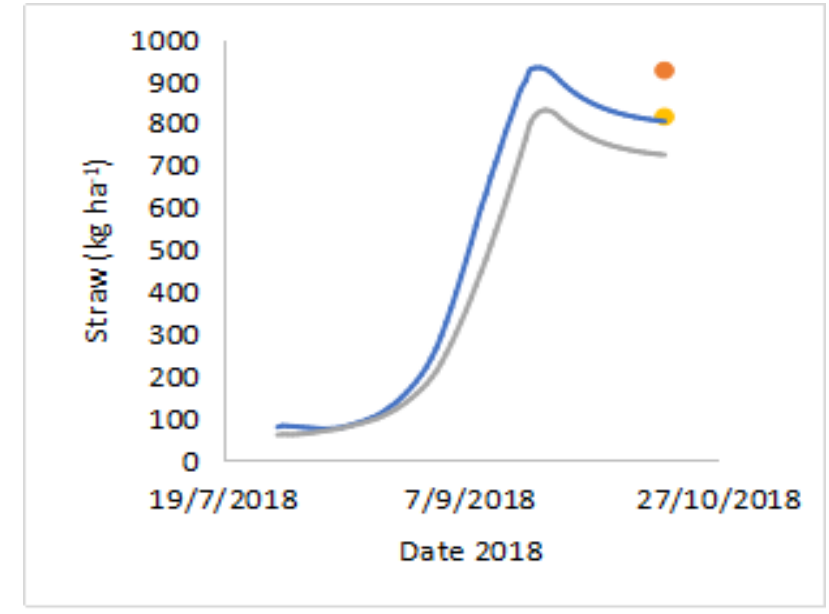

E. Biochar groundnut shells $+45 \mathrm{~N} 30 \mathrm{P} 30 \mathrm{~K}$
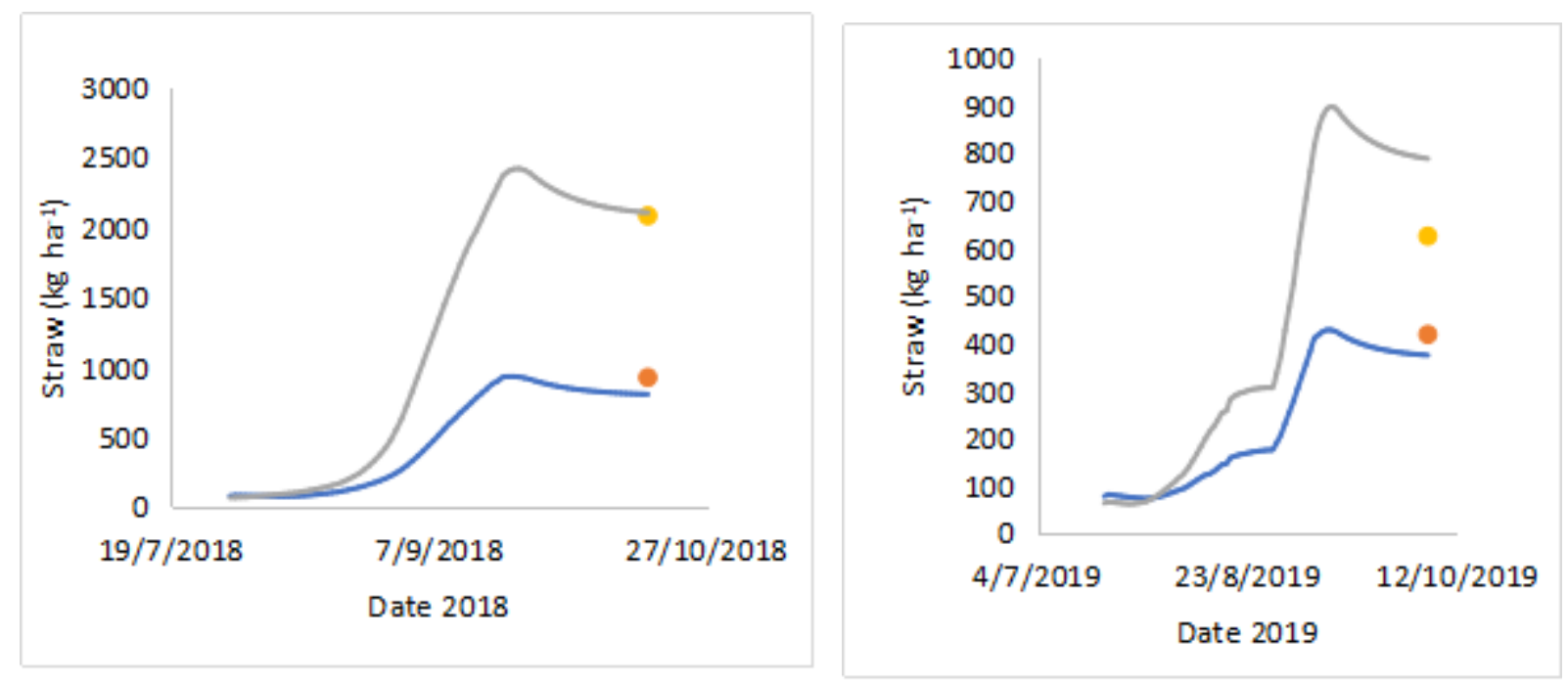

F. Biochar Corn cobs+45N30P30K
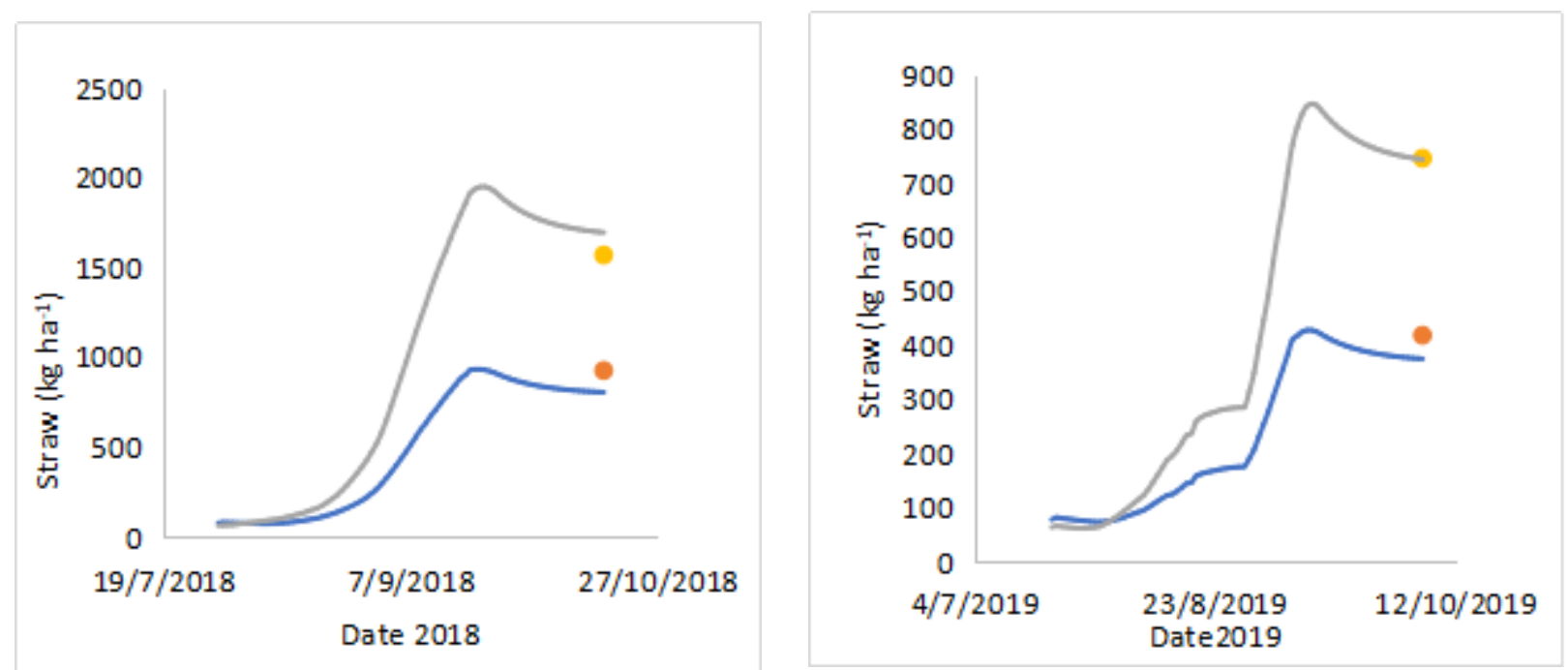

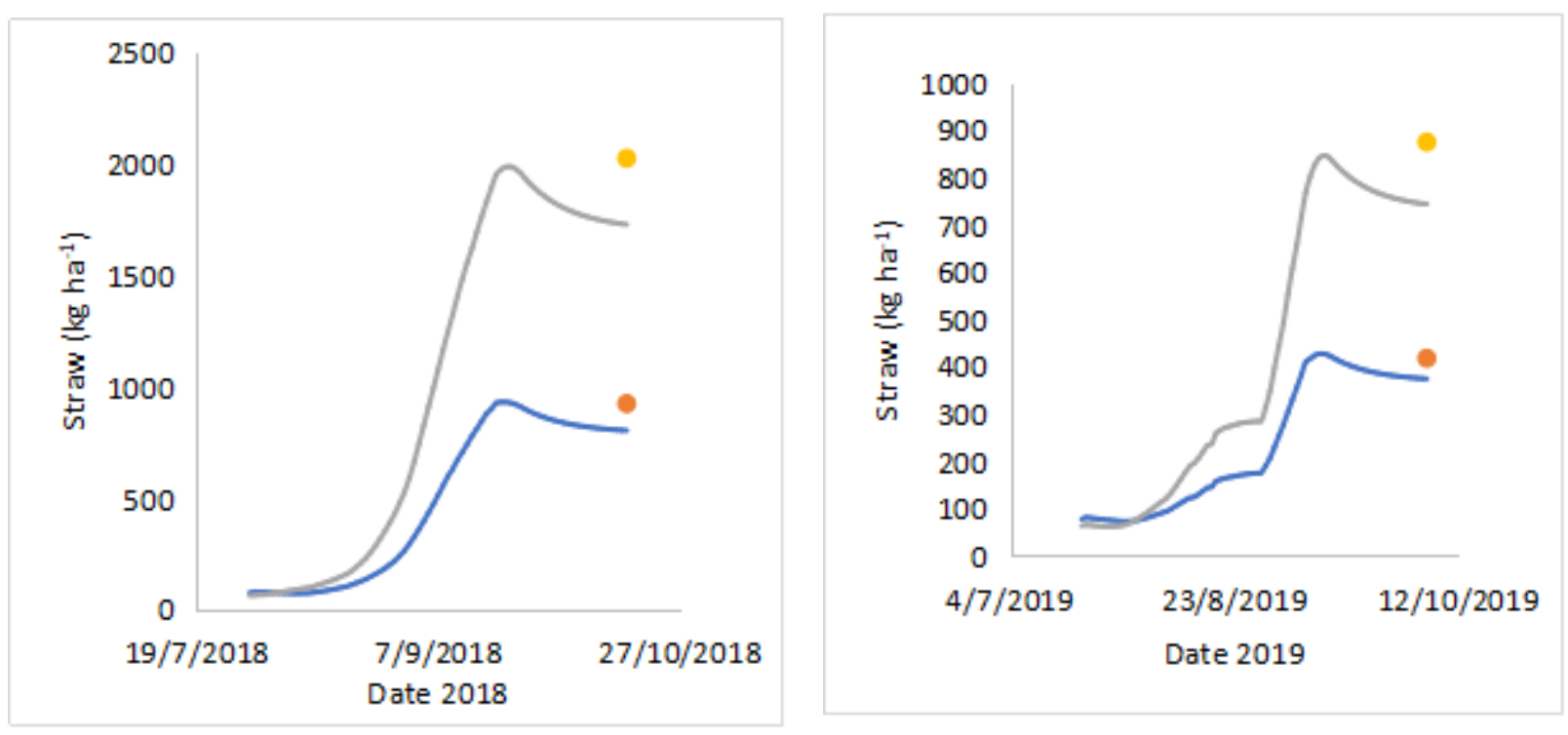

Figure 2. Measured and predicted straw production of rice-cowpea intercrop

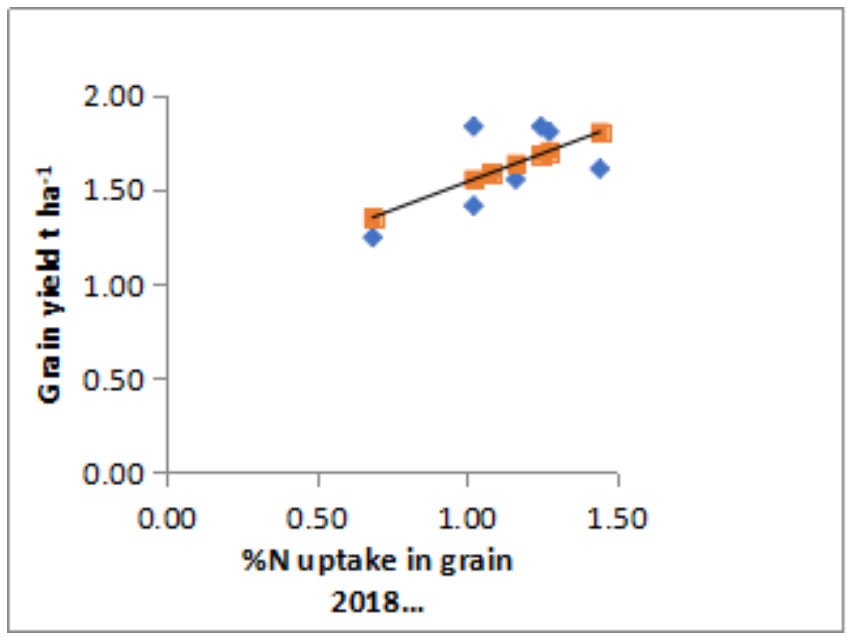

3a. char groundnut shells $+45 \mathrm{~N} 30 \mathrm{P} 30 \mathrm{~K}$. Relationship between grain yield and \%N uptake

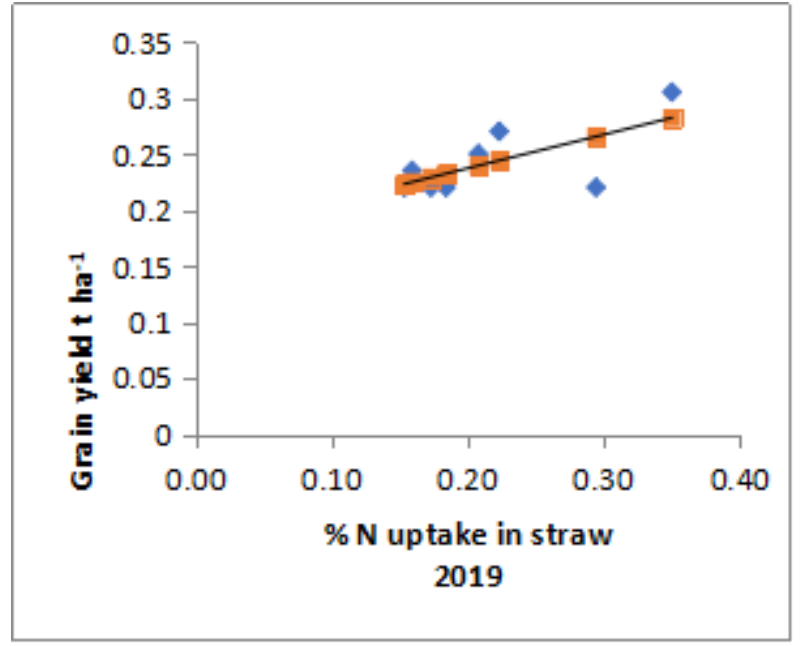

3b. char poultry manure+45 N30P30K. Relationship between grain yield and \%N uptake straw 


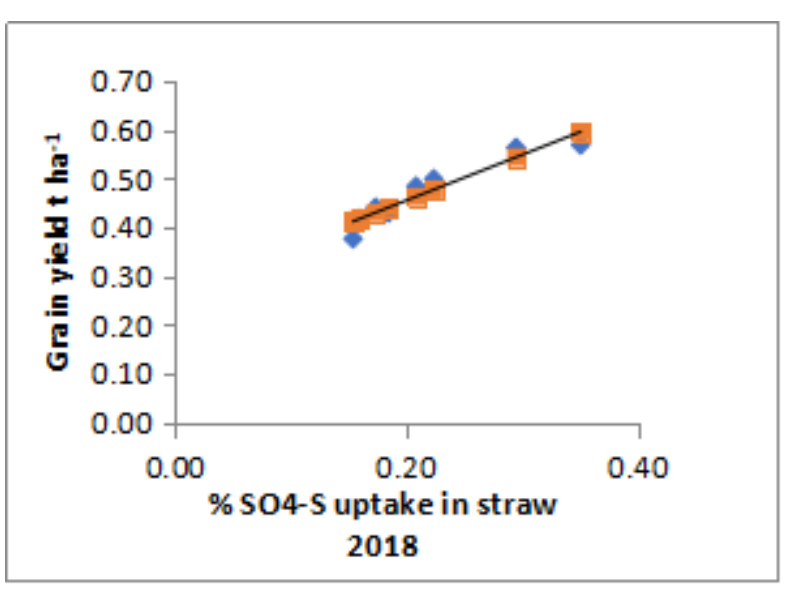

3c. char groundnutshells $+45 N 30 P 30 K$.

Relationship between grain yield and $\% \mathrm{SO}_{4}$ uptake

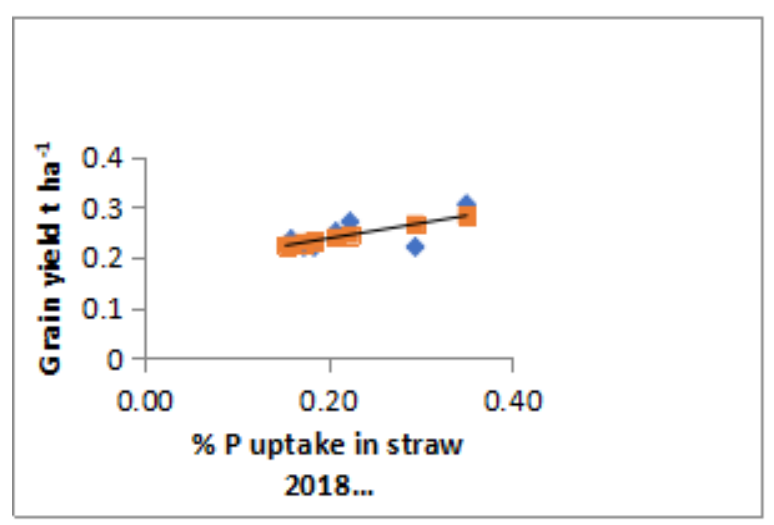

3e. 90N60P60K. Relationship between grain yield and \%P uptake straw

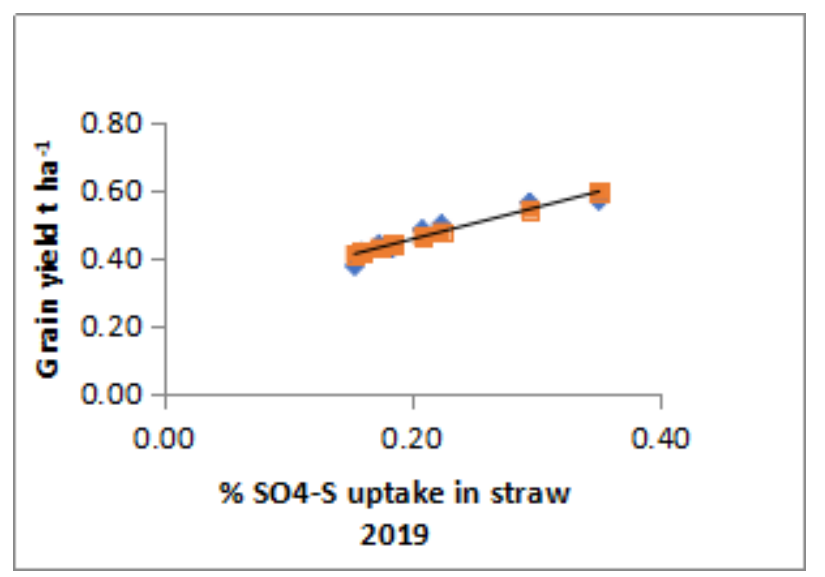

3d. char poultry manure $+45 \mathrm{~N} 30 \mathrm{P} 30 \mathrm{~K}$.

Relationship between grain yield and $\% \mathrm{SO}_{4}$ uptake straw

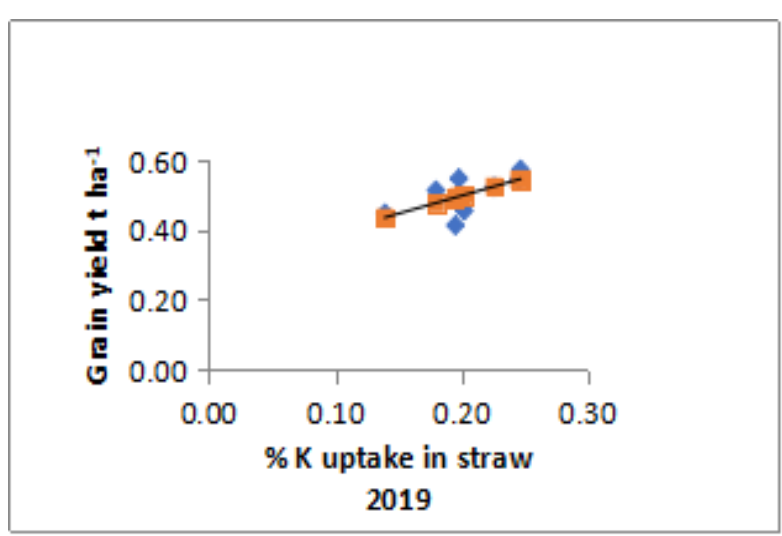

3f. char corncobs+45 N30P30K. Relationship between grain yield and \%K uptake straw

Figure 3a-e. Relationship between uptake nutrient and \% grain yields as affected by biochar and inorganic fertilizers. 


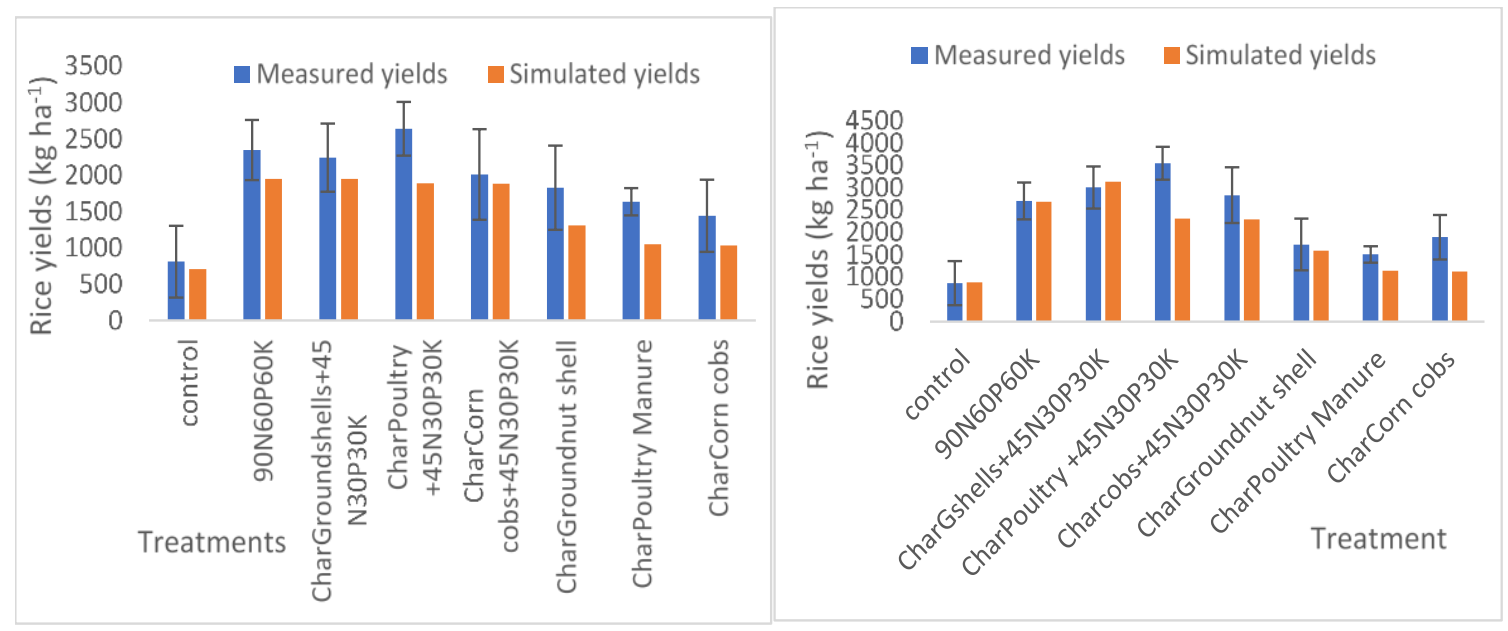

Figure $4 i$, ii. The simulated and measured of upland rice yield as affected by the three different sources of biochar and inorganic fertilizer

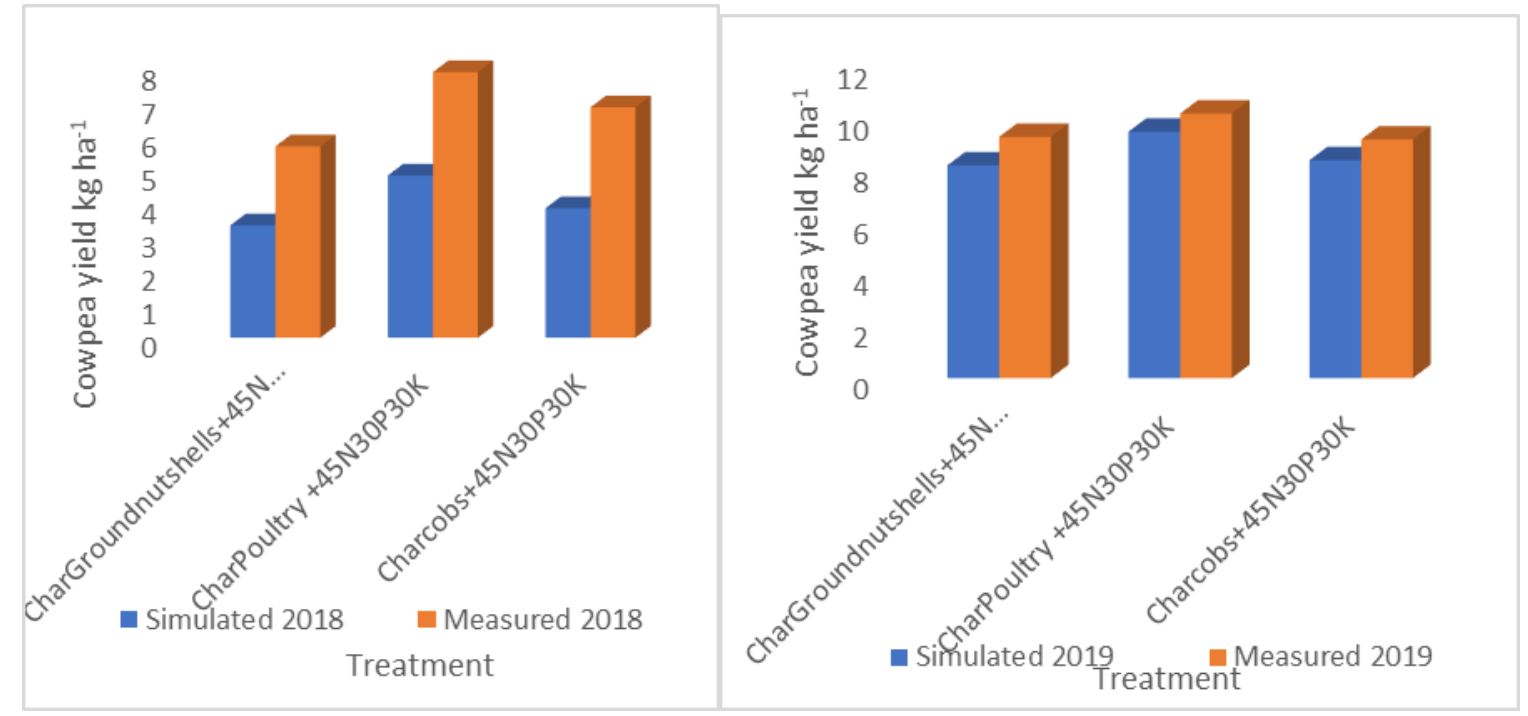

4a Simulated and measured cowpea yield

$4 \mathrm{~b}$ Simulated and measured cowpea yield

Figure 4ab.The simulated and measured of cowpea yield as affected by the three different sources of biochar and inorganic fertilizer 


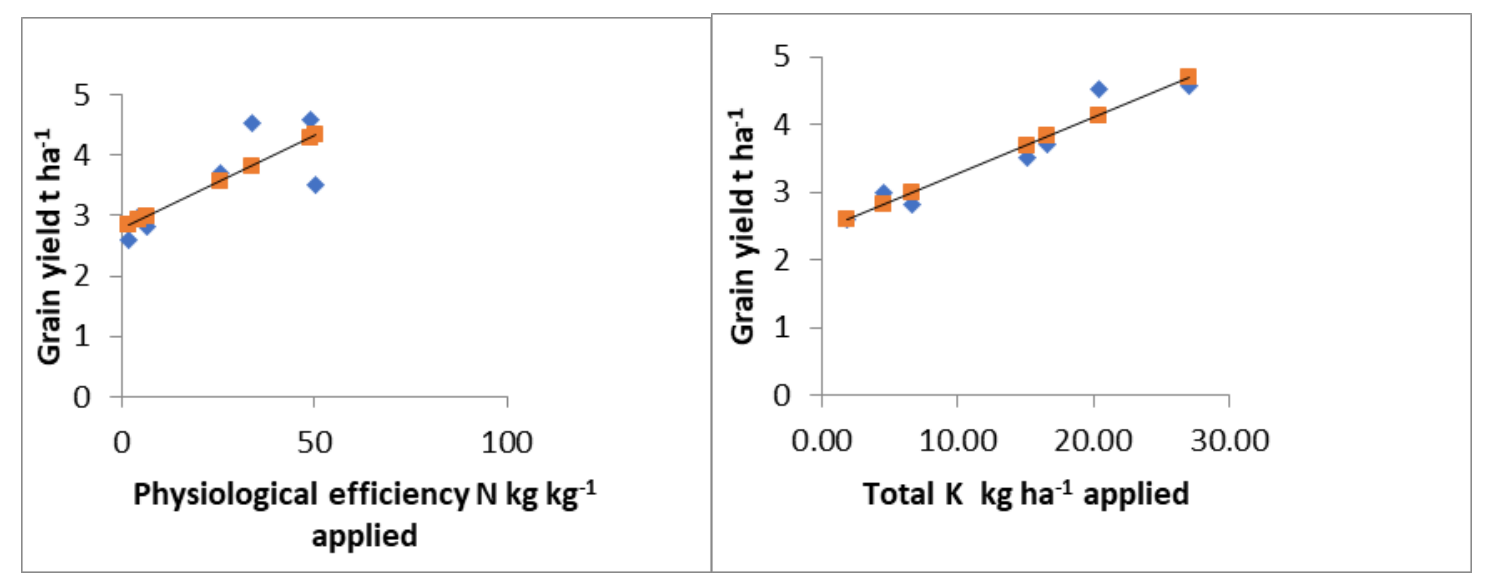

5a. (a) physiological efficiency of $N$ applied

(b) grain yield and total applied $K$

Figure 5a. Relation between grain yield and physiological efficiency of $N$ applied $(b)$ between grain yield and total applied $K$ of three different sources of biochar and inorganic fertilizer

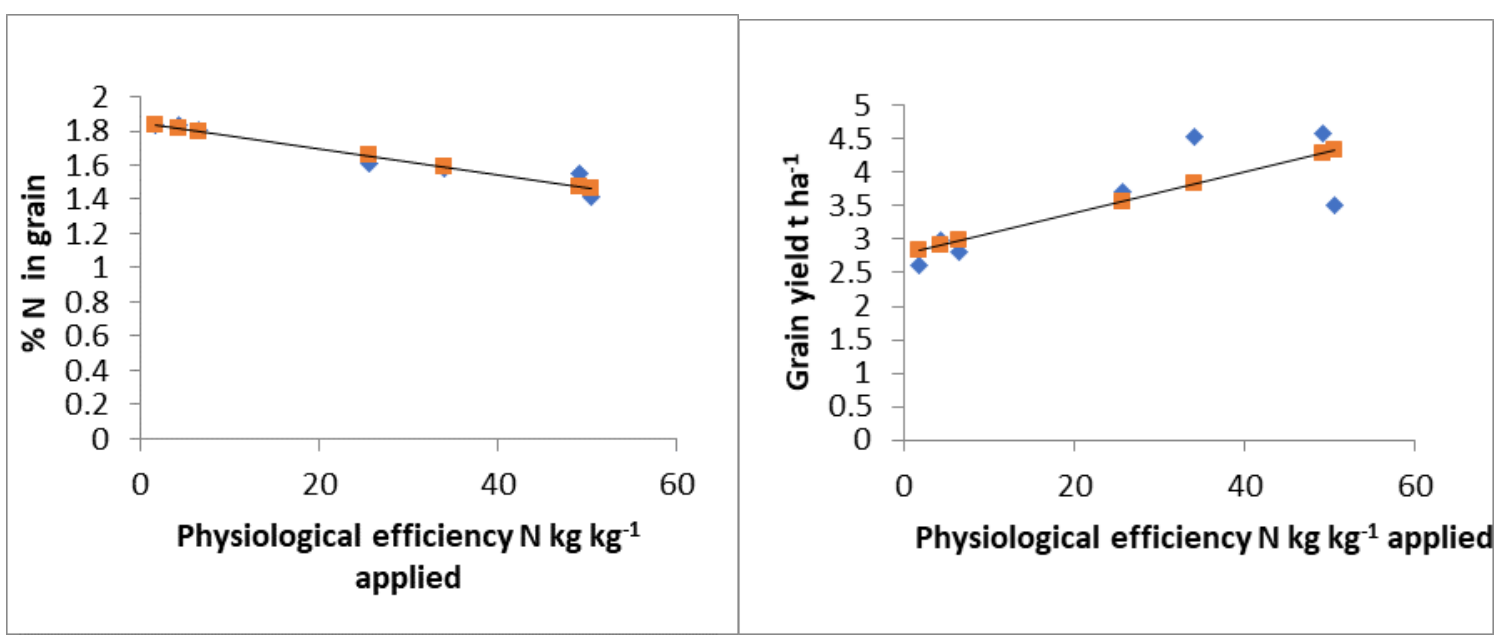

5b. (a) $\% \mathrm{~N}$ in grain

(b) physiological efficiency of $\mathrm{N}$ applied

Figure 5b. Relation between \% N in grain and physiological efficiency applied (b) grain yield and physiological efficiency of $\mathrm{N}$ applied by the three different sources of biochar and inorganic fertilizer 


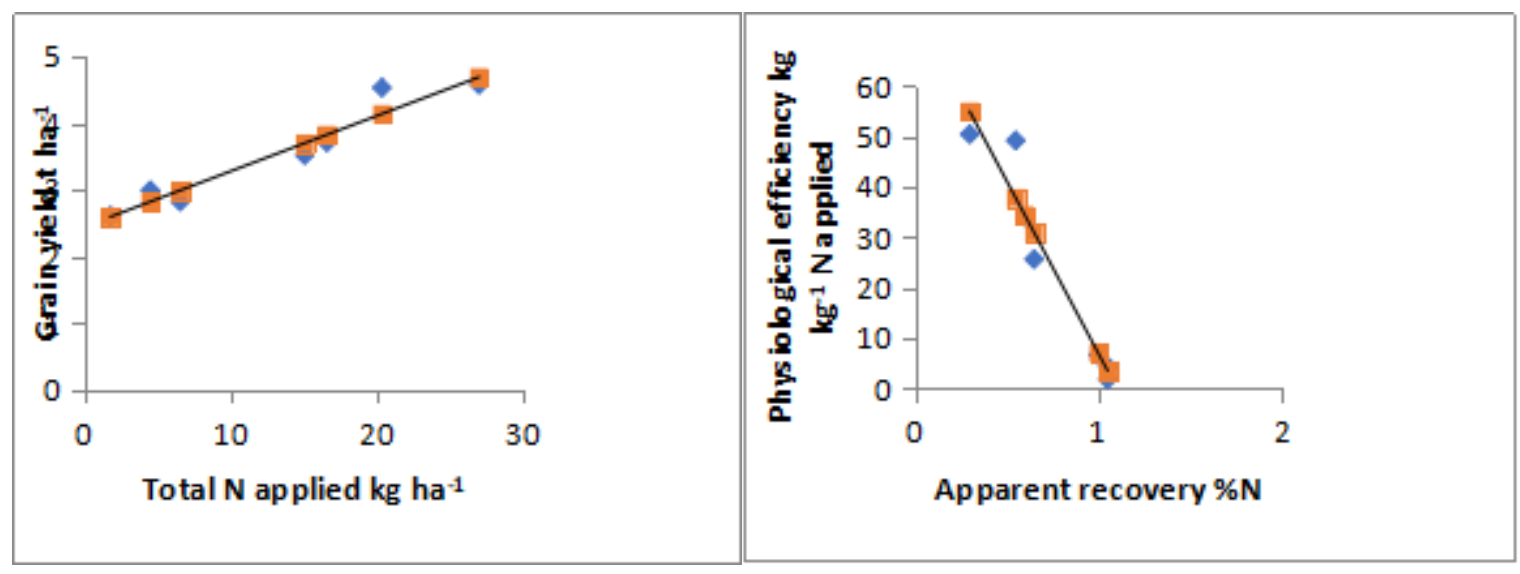

5c. (a) grain yield and total $N$ applied

(b) physiological efficiency of $N$ applied

Figure 5c. Relation between $N$ response in rice, (a) grain yield and total $N$ applied $(b)$ physiological efficiency of $N$ applied and apparent recovery $\% N$ applied of three different sources of biochar and fertilizer.

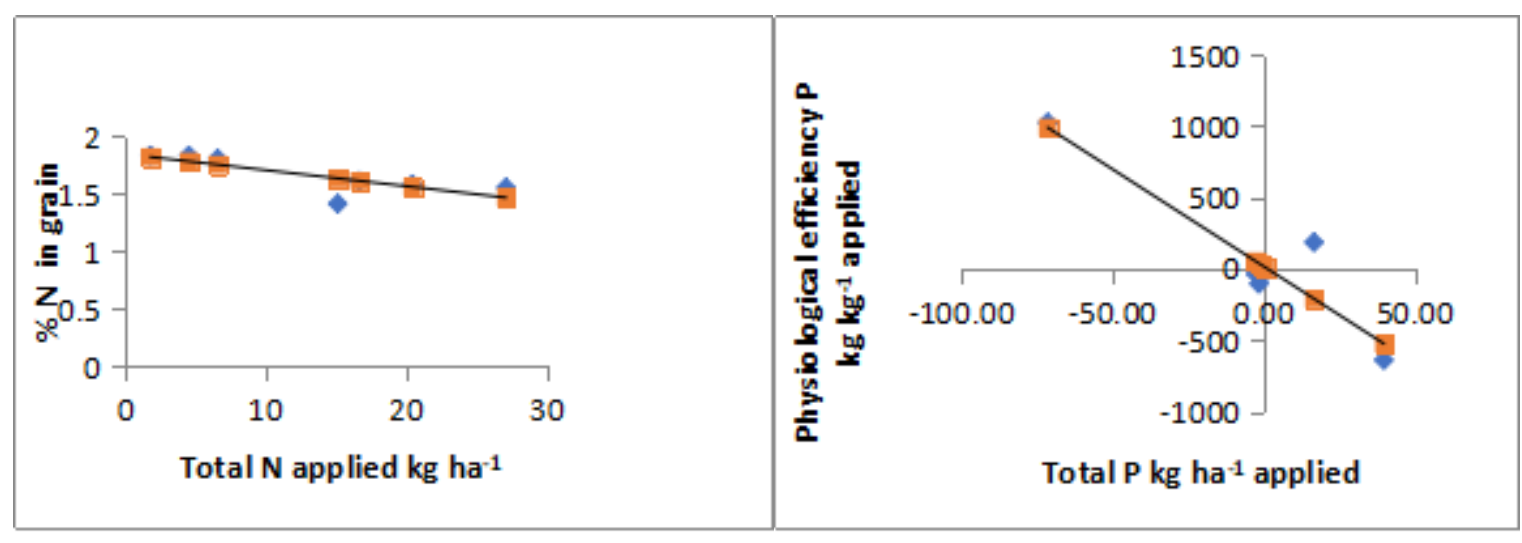

5d.(a) \% $N$ in grain and total $N$ applied $\quad$ (b) physiological efficiency of $P$

Figure 5d. (a) Relation between \% $N$ in grain and total $N$ applied (b) physiological efficiency of $P$ and total $P$ applied of three different sources of biochar and inorganic fertilizer.

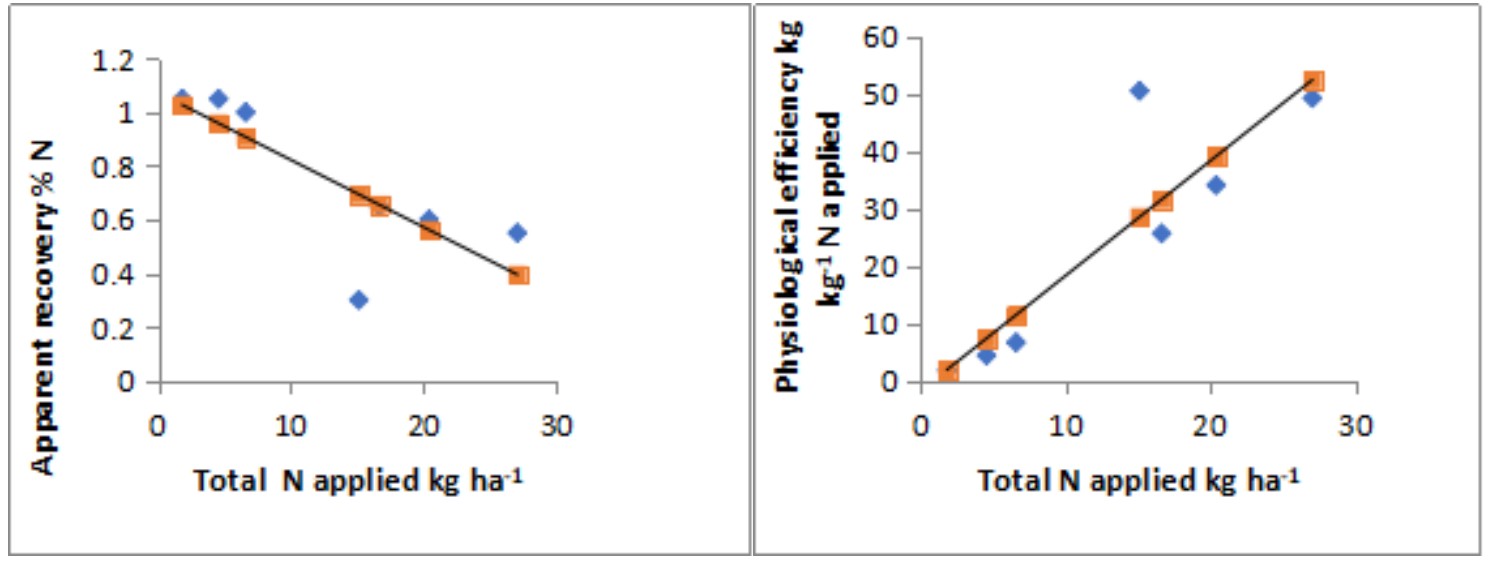

5e. (a) apparent $\% \mathrm{~N}$ recovery

(b) physiological $N$ efficiency 
Figure 5e. (a) Relation between apparent $\% N$ recovery and total $N$ applied (b) physiological $N$ efficiency and total $N$ applied of different sources of biochar.

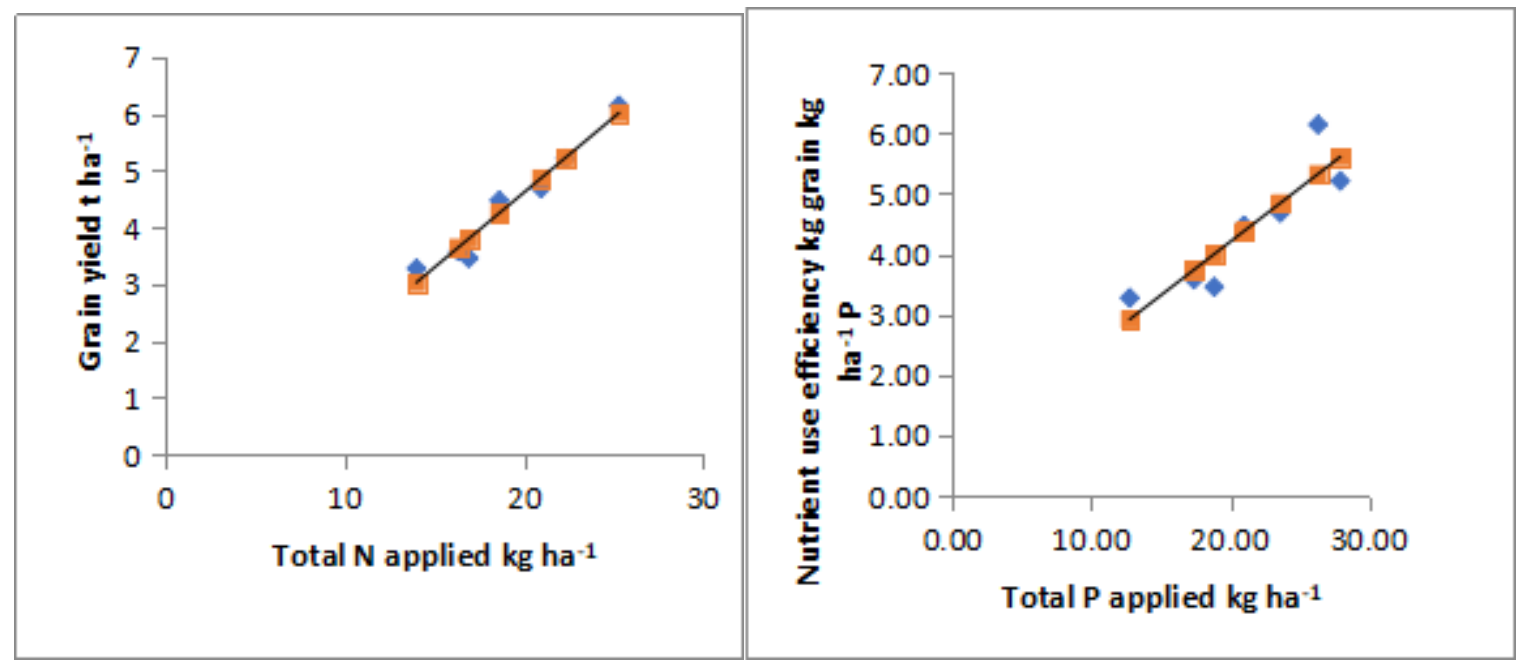

5f. (a) grain yield and total $N$ applied

( b) nutrient use efficiency $P$

Figure. 5f. (a) grain yield and total $N$ applied $(b)$ nutrient use efficiency $P$ and total $P$ applied of three different sources of biochar and inorganic fertilizer.

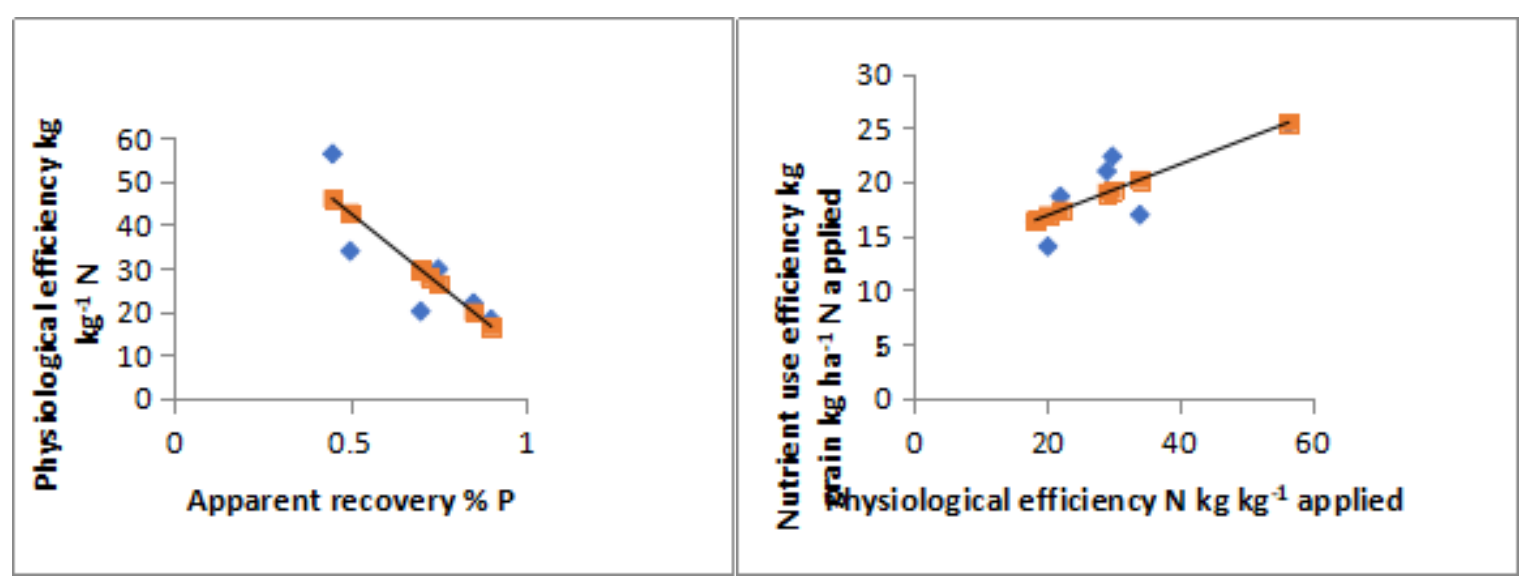

5g. (a) physiological $N$ efficiency

(b) nutrient use efficiency $N$ applied

Figure 5g. (a) Relation between physiological $N$ efficiency and apparent $N$ recovery (b) nutrient use efficiency $N$ applied and physiological efficiency $N$ applied of three different sources of biochar and inorganic fertilizer 


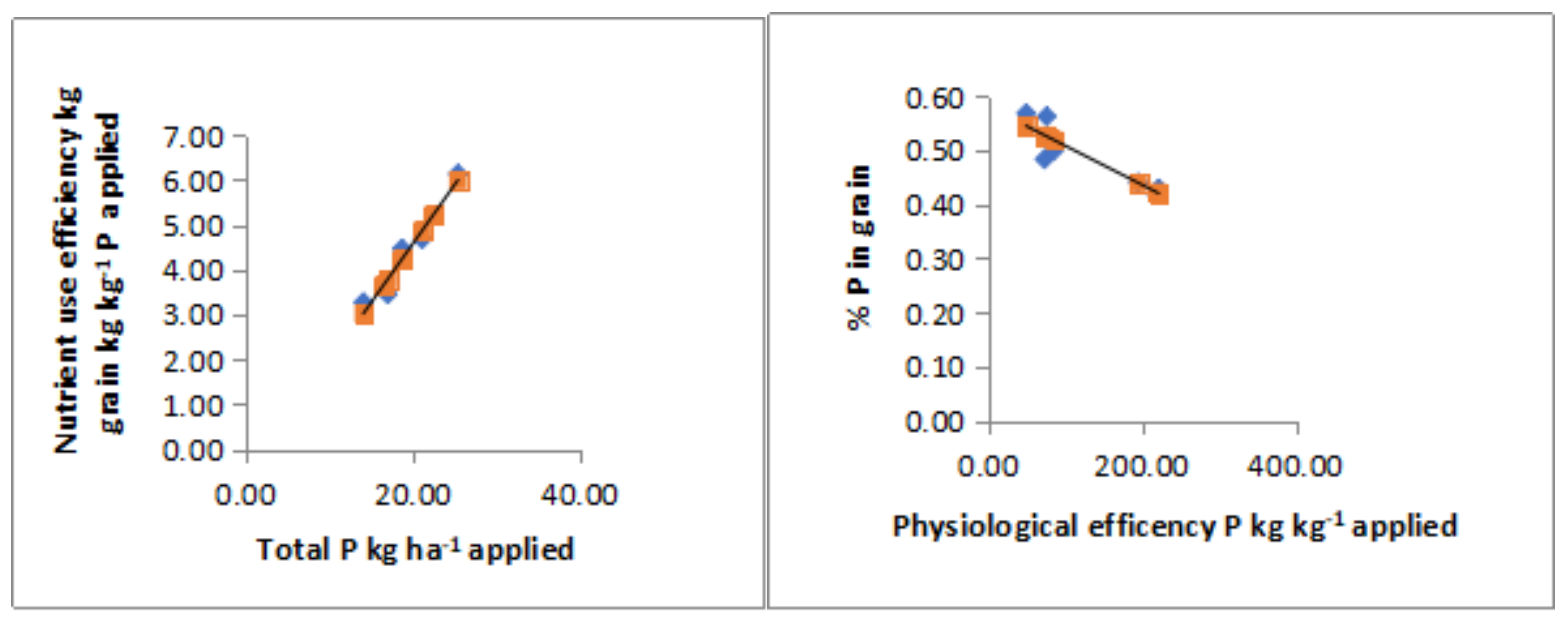

$5 h$ (a) nutrient use efficiency

5h. (b) physiological efficiency $P$

Figure. 5h (a) Relation between nutrient use efficiency of $P$ in grain and total $P$ applied $(b) \% P$ in grain and physiological efficiency $P$ applied of different sources of biochar and inorganic fertilizer.

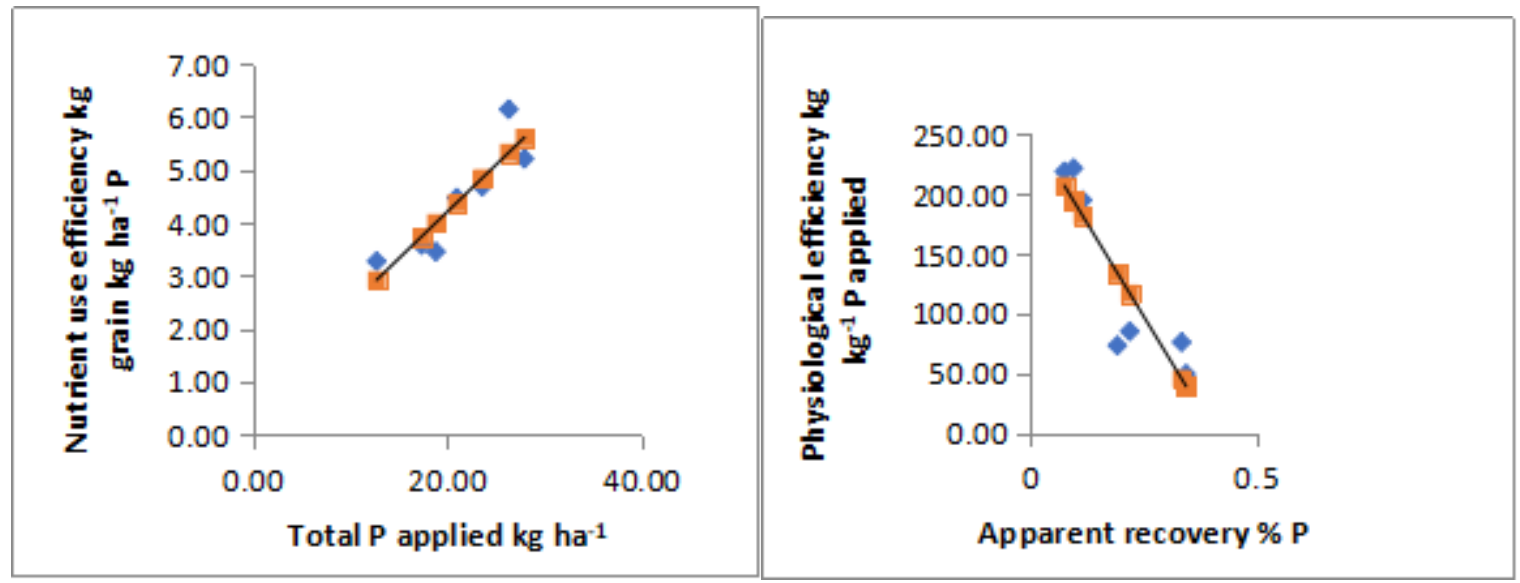

5i. (a) nutrient use efficiency $P$ in grain

5i.(b) physiological efficiency $P$ applied

Figure 5i. (a) Relation between nutrient use efficiency $P$ in grain and total $P$ applied $(b)$ physiological efficiency $P$ applied and apparent recovery \% $P$ of different sources of biochar 


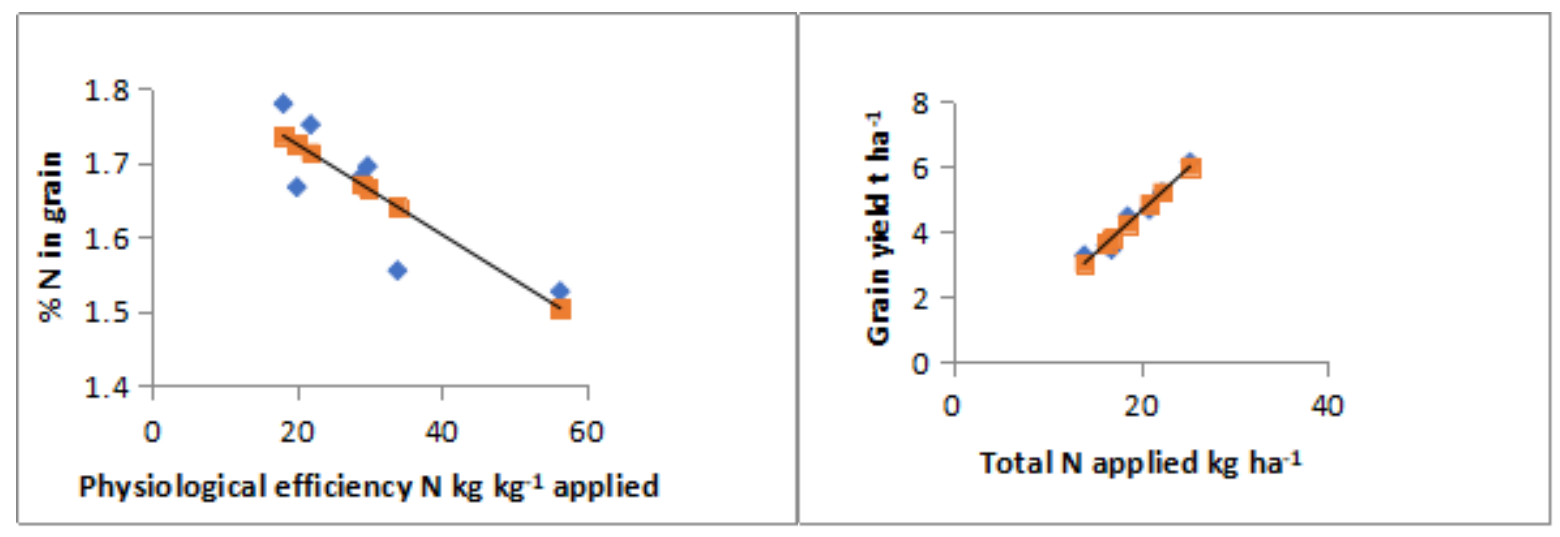

5j. a) \% N in grain and physiological efficiency $P \quad$ b) Grain yield and total $N$ applied

Figure 5j. (a) Relation between $\% N$ in grain and physiological efficiency $P$ applied (b) Grain yield and total $N$ applied of three different sources of biochar and inorganic fertilizer.

\section{Discussion}

\section{Treatments' effects on soil fertility}

On three different sources of biochar and control plots, an analysis of variance test revealed a significant $(\mathrm{p}<0.05)$ effect of cowpea intercrop, fertilizer, and their interactions on mineral $\mathrm{N}$, available P, and CEC (Figure 5c-e). Meanwhile, the impact was stronger in soils that received biochar amendments from three different sources. When cowpea intercrop and/or inorganic fertilizer were applied with three different sources of biochar, nitrogen availability rose by $114 \%$ compared to plots that did not receive biochar additions. In addition, on biochar-amended plots, cowpea intercrop and/or fertilizer application boosted $\mathrm{P}$ availability to almost twice that of control plots. A limited number of experiments have been conducted on the three different sources of biochar treatments with cowpea intercrop (Farhangi-Abriz et al., 2021; Bashagaluke et al., 2020), However, research has indicated that combining biochar with inorganic fertilizer improves soil $\mathrm{N}$ and $\mathrm{P}$ availability (Oladele et al., 2019; Mensah and Frimpong, 2018). Given the low nitrogen concentration and mineralization rate of the three different sources of biochar, the application of the three different sources biochar could not have contributed much (in terms of nutrient supply) to the increased $\mathrm{N}$ and $\mathrm{P}$ availability in soils applied with the three different sources biochar and cowpea intercrop and/or inorganic fertilizer treatments. The use of biochar from three different sources in such integrated treatment applications, on the other hand, could have reduced nutrient leaching and enhanced the soil's nutrient and water retention capacity (El-Naggar et al., 2019). Although nutrient leaching was not addressed in this study, it has been demonstrated to be reduced with the use of biochar, even on heavily weathered soils (Haider et al., 2017; Steiner et al., 2007). Table 1 showed, improved CEC with the three different sources biochar was also detected, which further approves that the soil's interaction ability and adsorption of accessible minerals and cations were enhanced with the three different sources of biochar application. It is well known that biochar application increases CEC (Tomczyk et al. 2020; Li et al. 2018). Meanwhile, in many regions of the semi-arid tropics, where soils with poor cation exchange capacity predominate, increasing CEC with the three main sources of biochar is critical, low-acidity sandy-loam soils that may lose their fertility quickly if fallow periods, or anything similar to fallow conditions, are not imposed (Mensah and Frimpong, 2018; Rawat et al., 2019). The substantial positive correlation established between CEC, inorganic $\mathrm{N}$, and available $\mathrm{P}$ demonstrated 
the importance and influence of CEC on soil nutrient availability on yield (Figure 4i, ii and 4a-b; 5c-e and 5a-j). This substantial relation also explains why, due to increased CEC, inorganic $\mathrm{N}$ and available $\mathrm{K}$ and $\mathrm{S}$ were highest, available $\mathrm{P}$ was moderate when cowpea intercrop and/or inorganic fertilizer were applied with biochar (Wibbing, 2020).

\section{Nutrient uptake in straw and grain}

Except for the uptake of $\mathrm{P}$, interactions between different sources of biochar +fertilizer influenced $(p<0.05)$ the uptake of all nutrients in straw (Table 3 and Figure 3a-e). At the level of the intercropping system, except for the second cropping season, the interaction between different sources of biochar $+45 \mathrm{~N} 30 \mathrm{P} 30 \mathrm{~K}$ influenced the uptake of all four nutrients. In all, rice straws under different sources of biochar $+45 \mathrm{~N} 30 \mathrm{P} 30 \mathrm{~K}$ with cowpea intercrop plots recorded higher $(\mathrm{p} \leq 0.05)$ nutrient uptake than those in the control (Table 3 ) in each of the cropping period. Nitrogen uptake in the straw was $1.44 \%$ and $1.41 \%$ for both cropping season more under biochar poultry manure+45N30P30K+cowpea plots compared to biochar poultry manure plots over the two-cropping season. Similar trends were observed for $\mathrm{S}$ and $\mathrm{K}$ with average increases in uptake of $0.57-0.58 \%$ and $1.80-2.94 \%$ respectively (Table 3 ). However, the magnitude of increases in $\mathrm{P}$ and $\mathrm{N}$ uptake in the straw was lower than that obtained for S. Additionally, uptake of nutrients during first cropping season were generally higher than those in the second cropping season. The uptake of $\mathrm{N}$ in grain was influenced by the interactions among different sources of biochar+ 45N30P $30 \mathrm{~K}$ with cowpea intercrop. The interactions between different sources of biochar $+45 \mathrm{~N} 30 \mathrm{P} 30 \mathrm{~K}$ influenced $(\mathrm{p} \leq 0.05)$ the uptake of $\mathrm{N}, \mathrm{P}, \mathrm{K}$ and $\mathrm{S}$ in grain. Additionally, the interaction between cowpea intercropping with different sources of biochar influenced $(\mathrm{p} \leq 0.05)$ the uptake of $\mathrm{N}$ and $\mathrm{P}$. At the intercropping period level, the interaction between biochar $+45 \mathrm{~N} 30 \mathrm{P} 30 \mathrm{~K}$ influenced $(\mathrm{p} \leq 0.05)$ nutrient uptake in all cropping period for the uptake of $\mathrm{N}, \mathrm{K}$ and $\mathrm{S}$ except $\mathrm{P}$ in the first and second cropping period. Figure 3 and Table 3 shows the nutrient uptake in response to different sources of biochar and fertilizer per each cropping season. The average uptake of $\mathrm{N}, \mathrm{P} \mathrm{K}$ and $\mathrm{S}$ in straw were higher under the different sources of biochar $+45 \mathrm{~N} 30 \mathrm{P} 30 \mathrm{~K}$ with cowpea intercrop by $\mathrm{r}^{2}=0.45,0.45,0.41$ and 0.89 respectively compared to those obtained under different sources of biochar $+45 \mathrm{~N} 30 \mathrm{P} 30 \mathrm{~K}$ application. The trend in nutrients uptake in grain were generally similar to those observed with nutrients uptake in straw. Except for K, uptake of nutrients was higher in the straw than in the grains. The uptake of nutrients in grain generally increased with increasing rates of $\mathrm{N}$ and $\mathrm{K}$ fertilizer. Nitrogen and phosphorus transfer from cowpea to rice plants grown in intercropping under biochar and inorganic fertilizer system, caused in higher filled panicle number, spikelet weight and weight of 1000 grain seeds of the rice plants in intercropping than in sole crop (Table 5a-b).

\section{Modeling upland rice growth and grain yield}

P-modules of other models like CENTURY were developed for soils where N-limiting conditions are mainly characterized by a minor impact of P-dynamics on crop growth (MacCarthy et al., 2009). However, APSIM seemed more appropriate for this study area as it was developed from data primarily from the semi-arid tropics, where resource-poor smallholders face limiting $\mathrm{P}$ conditions in soils (MacCarthy et al., 2009). Sahrawat et al. (2005) reported a reduction in plant response to P due to the high sorption capacity of $\mathrm{P}$ from soils and also observed that zinc deficiency in soils impeded corn responses to $\mathrm{P}$ application. The soils in the experimental field were classified as having low $\mathrm{P}$ 
sorption capacity. Obodai, 2018 also reported that the presence of 'laterite soil' rich in iron and aluminium reduces the response of $\mathrm{P}$ by being a well for $\mathrm{P}$, which does not make it accessible to crops. This was not a problem for this study because laterite soil was barely present in soils at a depth of 0-30 $\mathrm{cm}$. There is no doubt that nitrogen is the nutrient that most restricts agricultural production in the study area and is clearly visible in the performance of cereals (figure 4). All the same, its efficiency is diminished by the low $\mathrm{P}$ status of the soil. Both nutrients were deemed to be the most limiting to crop production (Tetteh et al., 2017). When farmers have the option of choosing a nutrient to focus on, based on their limited resources, it would make sense to opt for nitrogen fertilizers as they provide more revenue.

APSIM had a high predictive performance for grain yield with an internal model efficiency of 0.64. An inaccurate phenology prediction predisposes vital physiological growth processes to being incorrectly timed with erroneous dates that could coincide with adverse weather conditions. Upland rice phenological growth was generally well predicted. The delay in flowering observed under conditions of low intake (lack of application of biochar and inorganic N and $\mathrm{P}$ ) in absolute control is, however, overstated by the model. This proposes the need for $\mathrm{N}$ and $\mathrm{P}$ stress factors influencing phenology to be improved with considerations for highly weathered, low-input soils. Tetteh et al., 2017; Martey et al., 2014 also reported in its study of small-scale farms in semi-arid Ghana that the model predicted low cereal yields at low fertilizer utilization rates. This has been attributed to poor efficiency in the internal use of APSIM corn module nutrients at low soil $\mathrm{N}$ levels. APSIM has also been described to have performed creditably in predicting soil organic carbon dynamics in the semiarid area of Africa (Delve et al., 2009; Micheni et al., 2004). The level of $\mathrm{N}$ and $\mathrm{P}$ content in straw was also well predicted in this experiment (Figure 3a-e). This indicates good model performance in the prediction of soil processes such as soil water dynamics that are essential for the transport of nutrients from the soil to the root zone of plants as well as the transformation of nitrogen. The high (3.54 $\mathrm{t} \mathrm{ha}^{-1}$ ) general modified internal coefficient of efficiency in predicting upland rice grain and total biomass production and the ability of APSIM to simulate straw N and P contents, provides sufficient precision for a relative assessment of the long-term impact of farmers' management practices on future grain yield production. Figure 4a-d Measured and predicted upland rice grain and cowpea yields as affected by biochar and inorganic fertilizers.

\section{Physiological efficiency of $N, P$ and $K$ and apparent recovery efficiency of $N, P$ and $K$ applied}

The efficiency of fertilizer applied was evaluated by the physiological efficiency of nitrogen (PEN) fertilizer and the apparent recovery efficiency (ARE) of NPK fertilizer used. The PEN was influenced $(\mathrm{p} \leq 0.05)$ by the single effects of cropping season, $\mathrm{N}$ and $\mathrm{K}$ fertilizer, and three different sources of biochar (Table 4 and Figure 5a, b, c and 5j). At the level of individual cropping seasons, three different sources of biochar, $\mathrm{N}$, and $\mathrm{K}$, influenced PE positively (Table 4 and Figure 5a-c). There was a general trend of PE decreasing with increasing $\mathrm{P}$ fertilizer applied for the second cropping season. Increasing $\mathrm{P}$ use from $30 \mathrm{~kg} \mathrm{P} \mathrm{ha}^{-1}$ resulted in a PEP decline of between $34 \%$ under different sources of biochar and between 25 and 40\% under different sources of biochar+45N30P30K across the cropping season. PENs on three different sources of biochar+45N30P30K with cowpea intercrop were between $50 \%$ and $60 \%$ higher than those obtained under three different sources of biochar+45N30P30K application. The magnitude of PE in $\mathrm{N}$ and $\mathrm{K}$ was generally higher in the first and second cropping seasons. Except for the second cropping season, the highest $(\mathrm{p} \leq 0.05) \mathrm{PE} \mathrm{K}$ in each cropping season was obtained under three different sources of biochar $+45 \mathrm{~N} 30 \mathrm{P} 30 \mathrm{~K}$ with 
cowpea intercrop that received $30 \mathrm{~kg} \mathrm{~K} \mathrm{ha}^{-1}$. PE was influenced by the soil organic carbon content of the soil and grain $\mathrm{N}$ and $\mathrm{K}$ uptake (Table 3 and 4). The single effects of cropping season, three different sources of biochar+45N30P30K with cowpea intercrop influenced the apparent recovery efficiency of $N$ (ARE) (Table 4 and Figure 5a-j). At the level of the individual cropping season, the single effects of biochar $+45 \mathrm{~N} 30 \mathrm{P} 30 \mathrm{~K}$ with cowpea intercrop influenced $(\mathrm{p} \leq 0.05)$ ARE except for the second cropping season. Three different sources of biochar+45N30P30K with cowpea intercrop resulted in increased average ARE per season ranging between 20 and 30\% compared to the use of three different sources of biochar. Generally, ARE decreased with increasing P rates irrespective of the three different sources of biochar+45N30P30K with intercrop cowpea (Table 4 and Figure 5c-e and 5i-g). ARE were lower in the 2018 cropping season than in the 2019 cropping season. ARE also declined in the 2018 cropping season as the $\mathrm{K}$ rate of $30 \mathrm{~kg} \mathrm{ha}^{-1}$ was increased, but in $2019 \mathrm{~K}$ was increased. ARE was significantly influenced by $\mathrm{N}$ uptake in the grain (Table 3 and Figure 5c-e and 5ig). Nitrogen and phosphorus transfer from cowpea to rice plants grown in intercropping under biochar and inorganic fertilizer systems resulted in greater panicle number, spikelet weight, and weight of 1000 grain seeds of rice plants grown in intercropping than solely sole crop (Table 5a, b).

\section{Conclusions}

In Guinea Savannah, this study looked at how integrating three different sources of biochar and inorganic fertilizer to a cowpea intercrop could improve soil fertility and crop yields, improve SOC storage, NPK recovery, and physiological use efficiency, and boost rice yields. In the short term, integrating three different sources of biochar and inorganic fertilizer enhanced SOC storage, productivity, and average PE and ARE over the world averages of $20 \mathrm{~kg}_{\text {grain }} \mathrm{kg}^{-1} \mathrm{~N}$ and $60 \%$, respectively. High temperatures, on the other hand, increased evaporation, resulting in unfilled grains from both sole fertilizers use and integrated fertilizer and three different biochar sources. To ensure higher yield, the choice of intercropping is crucial to avoid the rice plant's reproductive period coinciding with temperatures exceeding $34{ }^{\circ} \mathrm{C}$. The utilization of three different biochar sources in upland rice has the potential to be employed as a climate change adaptation and mitigation measure. The fact that the beneficial effects of three different sources of biochar application lasted for two cropping seasons after a one-time application shows that biochar can help improve fertilizer efficiency in semi-arid tropical agricultural systems. To determine how long biochar will survive in the soil and have an impact on the environment, a long-term study is required (polycyclic aromatic hydrocarbons in soils and Greenhouse gas emission). Prior to disseminating the technology to farmers, proper training of extension officers will be required to ensure efficient production and application of the three different sources of biochar technology to increase productivity in upland rice. APSIM can serve as an investigative and decision-making tool in this environment to help achieve several productivity goals.

\section{Acknowledgments}

The field experiment was self-finance. Education and Supervisor support from the Department of Agricultural Engineering, University for Development Studies under the Faculty of Agriculture-Soil and Water Conservation and Management Department (2019-2021). The Soil Research Institute is thanked for laboratory analyses. I thank Dr. Kofi Frimpong-Anin, Gabriel Willie Quansah and Joseph Kudadam Korese for helpful comments in this manuscript. 


\section{References}

Adu, S.V. (1995). Soils of the Nasia basin. Memoir No. 6. Soil Research Institute. Kumasi.

Archontoulis, S. V., Miguez, F. E., and Moore, K. J. (2014). A methodology and an optimization tool to calibrate phenology of short-day species included in the APSIM PLANT model: application to soybean. Environmental modelling \& software, 62, 465-477.

Asekabta, K. N. (2018). Effects of tillage, cropping system and NPK fertilizer rate on performance of maize (zea mays L.) soybean (Glycine max L. (Merill) intercrop in the Guinea Savannah agroecological zone of Ghana (Doctoral dissertation).

Ata-Ul-Karim, S. T., Zhu, Y., Yao, X., and Cao, W. (2014). Determination of critical nitrogen dilution curve based on leaf area index in rice. Field Crops Research, 167, 76-85.

Bashagaluke, J. B., Logah, V., Sakordie-Addo, J., and Opoku, A. (2020). Nutrient uptake and productivity of four tropical cropping systems under biochar amendment. Agronomy Journal, 112(4), 2664-2675.

Basso, A. S., Miguez, F. E., Laird, D. A., Horton, R., and Westgate, M. (2013). Assessing potential of biochar for increasing water-holding capacity of sandy soils. Gcb Bioenergy, 5(2), 132-143.

Bationo, A., Kihara, J., Vanlauwe, B., Waswa, B., and Kimetu, J. (2007). Soil organic carbon dynamics, functions and management in West African agro-ecosystems. Agricultural systems, 94(1), $13-25$

Bremner, J. M. (1965). Total nitrogen. Methods of Soil Analysis: Part 2 Chemical and Microbiological Properties, 9, 1149-1178.

De Jager, I. (2013). Nutritional benefits of legume consumption at household level in rural areas of sub-Saharan Africa. Background document.

De Jager, I., Borgonjen-Van Den Berg, K. J., Giller, K. E., and Brouwer, I. D. (2019). Current and potential role of grain legumes on protein and micronutrient adequacy of the diet of rural Ghanaian infants and young children: using linear programming. Nutrition journal, 18(1), 1-16.

Delve, R. J., Probert, M. E., Cobo, J. G., Ricaurte, J., Rivera, M., Barrios, E., and Rao, I. M. (2009). Simulating phosphorus responses in annual crops using APSIM: model evaluation on contrasting soil types. Nutrient cycling in agroecosystems, 84(3), 293-306.

Dokoohaki, H., Miguez, F. E., Laird, D., Horton, R., and Basso, A. S. (2017). Assessing the biochar effects on selected physical properties of a sandy soil: an analytical approach. Communications in Soil Science and Plant Analysis, 48(12), 1387-1398.

Downie, A., Crosky, A., and Munroe, P. (2012). Physical properties of biochar. In Biochar for environmental management (pp. 45-64). Routledge.

El-Naggar, A., Lee, S. S., Rinklebe, J., Farooq, M., Song, H., Sarmah, A. K., and Ok, Y. S. (2019). Biochar application to low fertility soils: A review of current status, and future prospects. Geoderma, 337, 536-554.

FAO. 1988. FAO/UNESCO Soil Map of the World Revised legend, with corrections. World Soil Resources Report 60. Rome. (Reprinted as Technical Paper 20, ISRIC, Wageningen, 1994).

Farhangi-Abriz, S., Torabian, S., Qin, R., Noulas, C., Lu, Y., and Gao, S. (2021). Biochar effects on yield of cereal and legume crops using meta-analysis. Science of The Total Environment, 775, 145869.

Haider, G., Steffens, D., Moser, G., Müller, C., and Kammann, C. I. (2017). Biochar reduced nitrate leaching and improved soil moisture content without yield improvements in a four-year field study. Agriculture, ecosystems \& environment, 237, 80-94.

Haji, K. B. (2016). Performance of new released upland Nerica rice varieties under different combined rates of nitrogen and phosphorus fertilizers in Zanzibar (Doctoral dissertation, Sokoine University of Agriculture). 
Heggenstaller, A.H., M. Liebman, and Anex R.P. (2009). Growth analysis of biomass production in sole-crop and double-crop corn systems. Crop Sci. 49:2215- 2224.

Heggenstaller, A.H., R.P. Anex, M. Liebman, D.N. Sundberg, and Gibson. R. (2008.) Productivity and nutrient dynamics in bioenergy double-cropping systems. Agron. J. 100:1740-1748.

Herath, H. M. S. K., Camps-Arbestain, M., Hedley, M., Van Hale, R., and Kaal, J. (2014). Fate of biochar in chemically-and physically-defined soil organic carbon pools. Organic geochemistry, 73, $35-46$.

Holzworth, D. P., Snow, V., Janssen, S., Athanasiadis, I. N., Donatelli, M., Hoogenboom, G., ... and Thorburn, P. (2014). Agricultural production systems modelling and software: current status and future prospects. Environmental Modelling \& Software, 72, 276-286.

ISSS/ISRIC/FAO. 1998. World Reference Base for Soil Resources. World Soil Resources Report 84, FAO, Rome.

Keating, B. A., Carberry, P. S., Hammer, G. L., Probert, M. E., Robertson, M. J., Holzworth, D., and Smith, C. J. (2003). An overview of APSIM, a model designed for farming systems simulation. European journal of agronomy, 18(3-4), 267-288.

Klute, A., and Page, A. L. (1986). Methods of soil analysis. Part 1. Physical and mineralogical methods; Part 2. Chemical and microbiological properties (No. BOOK). American Society of Agronomy, Inc.

Kombiok, J. M., Safo, E. Y., and Quansah, C. (2005). Yield and nitrogen fixation of cowpea as affected by tillage and cropping systems in the Northern Savanna Zone of Ghana. West African Journal of Applied Ecology, 7(1).

Laird, D. A., Fleming, P., Davis, D. D., Horton, R., Wang, B., and Karlen, D. L. (2010). Impact of biochar amendments on the quality of a typical Midwestern agricultural soil. Geoderma, 158(3-4), 443-449.

Li, Y., Hu, S., Chen, J., Müller, K., Li, Y., Fu, W., and Wang, H. (2018). Effects of biochar application in forest ecosystems on soil properties and greenhouse gas emissions: a review. Journal of Soils and Sediments, 18(2), 546-563.

Loecke, T.D., C.A. Cambardella, and M. Liebman. 2012. Synchrony of net nitrogen mineralization and maize nitrogen uptake following applications of composed and fresh swine manure in Midwest U.S. Nutrient Cycling in Agroecosystems 93: 65-74.

MacCarthy, D. S., Sommer, R., and Vlek, P. L. (2009). Modeling the impacts of contrasting nutrient and residue management practices on grain yield of sorghum (Sorghum bicolor (L.) Moench) in a semi-arid region of Ghana using APSIM. Field crops research, 113(2), 105-115.

Martey, E., Wiredu, A. N., Etwire, P. M., Fosu, M., Buah, S. S. J., Bidzakin, J., and Kusi, F. (2014). Fertilizer adoption and use intensity among smallholder farmers in Northern Ghana: A case study of the AGRA soil health project. Sustainable Agriculture Research, 3(526-2016-37782).

Martinez-Feria, R. A., Castellano, M. J., Dietzel, R. N., Helmers, M. J., Liebman, M., Huber, I., and Archontoulis, S. V. (2018). Linking crop-and soil-based approaches to evaluate system nitrogen-use efficiency and tradeoffs. Agriculture, Ecosystems \& Environment, 256, 131-143.

McCown, R. L., Keating, B. A., Carberry, P. S., Hochman, Z., and Hargreaves, D. (2016). The coevolution of the Agricultural Production Systems Simulator (APSIM) and its use in Australian dryland cropping research and farm management intervention. In Agricultural system models in field research and technology transfer (pp. 149-175). CRC Press.

Mensah, A. K., and Frimpong, K. A. (2018). Biochar and/or compost applications improve soil properties, growth, and yield of maize grown in acidic rainforest and coastal savannah soils in Ghana. International Journal of Agronomy, 2018. 
Micheni, A., Kihanda, F., and Irungu, J. (2004). Soil organic matter (SOM): The basis for improved crop production in arid and semi-arid climates of eastern Kenya. Managing nutrient cycles to sustain soil fertility in sub-Saharan Africa, 608.

Mohanty, M., K. Sammi Reddy, M.E. Probert, R.C. Dalal, A. Subba Rao, and N.W. Menzies. (2011). Modeling $\mathrm{N}$ mineralization from green manure and farmyard manure from a laboratory incubation study. Ecol. Modeling 222:719-726. doi: 10.1016/j.ecolmodel.2010.10.027

Nelson, W. (2020). Investigating Resource Competition in Cereal-legume Intercropping Systems (Doctoral dissertation, Georg-August-Universität Göttingen).

Obeng, H. B. (2000). Characterization and classification of some ironpan soils of Ghana.

Obodai, M. S. (2018). Phosphorus Fractions of Biochar-Amended Plinthalqualf under Clean and Waste Water Irrigation Regimes in Northern Ghana (Doctoral dissertation, University of Ghana).

Oladele, S. O., Adeyemo, A. J., and Awodun, M. A. (2019). Influence of rice husk biochar and inorganic fertilizer on soil nutrients availability and rain-fed rice yield in two contrasting soils. Geoderma, 336, 1-11.

Probert, M. E., Delve, R. J., Kimani, S. K., and Dimes, J. P. (2005). Modelling nitrogen mineralization from manures: representing quality aspects by varying C: N ratio of sub-pools. Soil biology and Biochemistry, 37(2), 279-287.

Rawat, J., Saxena, J., and Sanwal, P. (2019). Biochar: a sustainable approach for improving plant growth and soil properties. Biochar-an imperative amendment for soil and the environment, 1-17.

Sahrawat, K. L. (2005). Fertility and organic matter in submerged rice soils. Current science, 735739.

Steiner, C., Teixeira, W. G., Lehmann, J., Nehls, T., de Macêdo, J. L. V., Blum, W. E., and Zech, W. (2007). Long term effects of manure, charcoal and mineral fertilization on crop production and fertility on a highly weathered Central Amazonian upland soil. Plant and soil, 291(1), 275-290.

Streubel, J. D., Collins, H. P., Garcia-Perez, M., Tarara, J., Granatstein, D., and Kruger, C. E. (2011). Influence of biochar on soil $\mathrm{pH}$, water holding capacity, nitrogen and carbon dynamics. Soil Sci. Soc. Am. J, 75, 1402-1413.

Tetteh, F. M., Quansah, G. W., Frempong, S. O., Nurudeen, A. R., Atakora, W. K., and Opoku, G. (2017). Optimizing fertilizer use within the context of integrated soil fertility management in Ghana. Fertilizer use optimization in Sub-Saharan Africa. CAB International, Nairobi, Kenya, 67-81.

Tomczyk, A., Sokołowska, Z., and Boguta, P. (2020). Biochar physicochemical properties: pyrolysis temperature and feedstock kind effects. Reviews in Environmental Science and Bio/Technology, 19(1), 191-215.

Van Ittersum, M. K., Van Bussel, L. G., Wolf, J., Grassini, P., Van Wart, J., Guilpart, N., and Cassman, K. G. (2016). Can sub-Saharan Africa feed itself? Proceedings of the National Academy of Sciences, 113(52), 14964-14969.

Wibbing, J. R. (2020). Utilization of alternative phosphorus resources by regenerative agriculture practice based on mycorrhizal fungi and bio stimulants for restoration of Lake Chamo watershed, Ethiopia (Doctoral dissertation, Technische Universität Hamburg).

Zhang, F., Cui, Z., Fan, M., Zhang, W., Chen, X., and Jiang, R. (2011). Integrated soil-crop system management: reducing environmental risk while increasing crop productivity and improving nutrient use efficiency in China. Journal of Environmental Quality, 40(4), 1051-105 